\title{
Mixed-Severity Wildfire as a Driver of Vegetation Change in an Arizona Madrean Sky Island System, USA
}

\author{
Helen M. Poulos ${ }^{1, *(\mathbb{C}, \text { Michael R. Freiburger }}{ }^{1}$, Andrew M. Barton ${ }^{2}\left(\mathbb{D}\right.$ and Alan H. Taylor ${ }^{3}$ \\ 1 College of the Environment, Wesleyan University, Middletown, CT 06459, USA; mfreiburger@wesleyan.edu \\ 2 Department of Biology, University of Maine at Farmington, Farmington, ME 04938, USA; barton@maine.edu \\ 3 Department of Geography, The Pennsylvania State University, University Park, PA 16802, USA; aht1@psu.edu \\ * Correspondence: hpoulos@wesleyan.edu
}

Citation: Poulos, H.M.; Freiburger, M.R.; Barton, A.M.; Taylor, A.H. Mixed-Severity Wildfire as a Driver of Vegetation Change in an Arizona Madrean Sky Island System, USA. Fire 2021, 4, 78. https://doi.org/ $10.3390 /$ fire 4040078

Academic Editor: Eva K. Strand

Received: 19 August 2021

Accepted: 12 October 2021

Published: 20 October 2021

Publisher's Note: MDPI stays neutral with regard to jurisdictional claims in published maps and institutional affiliations.

Copyright: (c) 2021 by the authors. Licensee MDPI, Basel, Switzerland. This article is an open access article distributed under the terms and conditions of the Creative Commons Attribution (CC BY) license (https:/ / creativecommons.org/licenses/by/ $4.0 /)$.

\begin{abstract}
Fire is a powerful natural disturbance influencing vegetation patterns across landscapes. Recent transitions from mixed-species forests to post-fire shrublands after severe wildfire is an increasingly prevalent phenomenon in pine-oak and conifer forest ecosystems in southwestern North America. However, we know little about how variation in fire severity influences other common forest types in the region. In this study, we evaluated fire-induced changes in woody plant community composition and forest structure in Chiricahua Mountains in southeastern Arizona in the United States that hosts a diverse set of vegetation types. Cluster analysis of the pre-fire vegetation data identified three dominant pre-fire vegetation types including juniper woodland, piñon forest, and pine-oak forest. All vegetation types experienced significant tree mortality across a wide range of size classes and species, from forests to shrublands. The magnitude of change within sample plots varied with fire severity, which was mediated by topography. Significant shifts in dominance away from coniferous obligate seeder trees to resprouting hardwoods and other shrubs occurred across all vegetation types in response to the fire. Regeneration from seed can be episodic, but projected increases in aridity and fire frequency may promote continued dominance by hardwoods and fireand drought-resistant shrub communities, which is a regional forest management concern as wildfire size and severity continue to increase throughout the southwestern USA.
\end{abstract}

Keywords: fire severity; Madrean vegetation; Sky Islands; piñon-juniper woodlands; resprouting; vegetation change; vegetation recovery

\section{Introduction}

Fire is a powerful ecological disturbance that regulates plant species composition and vegetation structure in fire-adapted ecosystems worldwide [1-4]. Topography, climate, fire weather, and vegetation are major drivers of spatio-temporal variation in fire behavior within fire-prone systems, which interact to generate landscape mosaics of burn severity and fire effects on vegetation [5-15]. The Sky Island ecosystems of southwestern North America display considerable variation in fire regimes across topographic gradients and among vegetation types [16-18]. Historically frequent, low-severity surface fires were common within lower-elevation semi-desert grasslands, savannas, and pine-oak forests throughout this region. Within these vegetation types, frequent fires prevented shrub invasion of grasslands, maintained open woodlands, and promoted a mixture of woody plants with diverse fire persistence strategies $[16,19,20]$. In contrast, piñon and juniper woodlands and high-elevation mixed-conifer forests historically experienced fires with more mixed effects, including some stand-replacing fires [21-26]. Such variation in fire regimes in the Sky Islands has promoted a wide range of fire resistance and recovery mechanisms for woody plant persistence within these fire-prone environments.

Fire frequency and burn severity patterns are changing rapidly throughout southwestern North America in response to increasing aridity from climate change and more than a century of fuel accumulation under fire suppression [27-29]. Burn severity is increasing 
within pine-oak forests where live and surface fuel loads are high due to fire suppression [28-31], and within this vegetation type, high-severity, wildfire-driven transitions to shrublands are a well-documented phenomenon [32-36]. Recent high-severity fires in pine-oak forests at many sites have promoted the recovery of resprouters but less post-fire regeneration by obligate seeder taxa $[32,34,35,37,38]$. Stand-replacing fires within Sky Island mixed-conifer forests have similarly resulted in a loss of conifers and post-fire regeneration by resprouter plant taxa [21]. Comparatively little information exists, however, to characterize the effects of shifting fire regimes on plant survival and regeneration within Sky Island vegetation types on drier sites dominated by piñon pines, junipers, and shrubs.

As in pine-oak forests, woody plants within desert grasslands, piñon-juniper woodlands, and shrub-dominated chaparral cover types also generally either adopt a resprouter or obligate seeder post-fire regeneration strategy. For example, in contrast to pine-oak forests where pines have adopted a fire resister strategy for surviving frequent surface fire through thick bark, piñon pines are typically classified as thin barked, fire sensitive trees [39]. Oak and juniper associates within these piñon forests juniper woodlands generally adopt a resprouter regeneration strategy in response to fire, just like the oaks within the pine-oak forest type. Semi-desert grasslands and shrublands similarly host woody plants with a range of fire adaptations [40]. For example, pointleaf manzanita (Arctostaphylos pungens Kunth) is a seed-banking, obligate-seeder shrub that can also layer by putting out roots from branches that touch the ground [41]. Although we understand the regeneration response of some of the major woody plant species within these vegetation types, the fire survival and persistence strategies of many species are not well-understood.

The intensification of wildfire in southwestern North America is a critical management concern, which is compounded in the Sky Islands by the lack of knowledge about fire responses across the entire suite of shrub, woodland, and forest vegetation types. We also poorly understand how fire severity and topography interact to influence vegetation dynamics in response to fire among these diverse plant community types. This study compares contemporary wildfire effects on plant community composition and forest stand structure across a range of Sky Island vegetation types in response to the 2011 Horseshoe Two Fire. During the exceedingly dry year of 2011, this 90,226-ha fire burned through three quarters of the Chiricahua Mountains in southeastern Arizona which experienced mixed severity fire effects (12.4\% high-, $29.7 \%$ moderate-, 38\% at low-severity, and $19.8 \%$ unburned) [42]. The specific objective of this study was to evaluate the effects of the Horseshoe Two Fire using repeated measures woody plant abundance data from before (2002/2003) and after (2017/2018) the Horseshoe Two Fire in Chiricahua National Monument (CHIR) by quantifying fire-induced changes in woody plant species composition, abundance, and size structure across the fire severity and topographic gradients in CHIR.

\section{Materials and Methods}

\subsection{Study Area}

This study was conducted in Chiricahua National Monument (CHIR) of southeastern Arizona (Figure 1) within the Sky Islands Madrean Archipelago which is part of the northern edge of the Sierra Madre Occidental range that extends from Jalisco in southern Mexico to southern Arizona and New Mexico in the United States [43]. The mountain range runs $80 \mathrm{~km}$ southeast to northwest with an elevation that spans approximately 1100-2228 m altitude (a.s.l.) within CHIR. The terrain is rugged and heavily dissected, consisting of broad flat basins and rocky uplands, divided by steep canyon walls that drain into Sulfur Springs Valley. Soils are shallow and mostly derived from volcanic rhyolites and monzonites deposited in the early- to mid- Miocene; however, pre-tertiary rock is prominent at lower elevations [44].

The climate is arid to semiarid and with two wet seasons. The North American Monsoon occurs between July and September when more than $50 \%$ of total precipitation falls. The second period of precipitation occurs in winter, between December and March, which is followed by a distinct dry season [45]. Average minimum and maximum temperatures 
are -0.2 and $14.7 \mathrm{C}$ in January, respectively, and 17.4 and $32.8 \mathrm{C}$, respectively, in July. The mean annual rainfall at the visitor's center of Chiricahua National Monument (1650 m a.s.1.) is $492 \mathrm{~mm}$.

The biogeographical convergence of the Sierra Madre and the Rocky Mountains ranges with the Sonoran and Chihuahuan Deserts promotes high biological diversity and endemism throughout the region $[19,43]$. Steep elevation gradients and highly dissected topography are strong influences on vegetation distribution patterns within CHIR [46]. Major tree species include oaks (Quercus emoryi Torr, Q. hypoleucoides Camus, Q. toumeyi Sarg., Q. rugosa Nee, and Q. arizonica Sarg.), junipers (Juniperus deppeana Steud. and J. monosperma Engelm.), pines (Pinus discolor Hawksworth, P. leiophylla var. chihuahuana Shaw, P. engelmannii Carr., and P. arizonica Engelm.), cypress (Hersperocyparis arizonica Bartel), and Douglas-fir (Pseudotsuga menziesii Franco), and their distribution varies according to local site conditions [16]. A wide variety of shrub species are intermixed with trees throughout CHIR, and dominance patterns across the landscape are driven by soil moisture and topography [16]. Common shrubs include Nolina macrocarpa Wats, Arctostaphylos pungens Kunth, Garya wrightii Torr., and Dasylirion wheeleri Wats. Higher elevations in the Chiricahua Mountains, but outside CHIR, are dominated by aspen and mesic mixed-conifer forests above $2590 \mathrm{~m}$ elevation [47,48]. Nomenclature follows USDA [49].

Historically, Madrean pine-oak forests in canyons and at intermediate elevations supported a frequent surface fire regime (mean fire interval $4-6$ years) [50,51]. In contrast, both higher-elevation mixed-conifer forests and piñon-juniper-oak-shrub vegetation on drier, lower elevation sites burned less frequently and experienced fires with variable severity, including infrequent stand-replacing fires $[25,26]$. The 2011 Horseshoe Two Fire was the first contemporary landscape fire to burn through CHIR since 1924 [52]. Within the Monument, the fire was a mixed-severity fire that burned through $93 \%$ of the landscape (36\% at low-, $41 \%$ at moderate, and $16 \%$ at high-severity based on monitoring trends in burn severity data [53]). The Horseshoe Two Fire was the only major disturbance that occurred in CHIR over the 2002/3 and 2017/8 sampling interval; we therefore attributed changes in the vegetation complex over this period to the wildfire.

\subsection{Field Sampling Methods}

We evaluated changes in woody plant species composition and forest stand structure in response to the Horseshoe Two Fire by resampling a 138 geo-referenced vegetation transects established in 2002 and 2003 prior to the fire. Post-fire sampling occurred over two years in 2017 and 2018, or 6-7 years after the fire. Plots were distributed over a wide range of topographic settings, vegetation types, and fire severities, spanning from no fire to high-severity fire.

Vegetation was sampled in $5 \times 25 \mathrm{~m}(0.125$-ha) belt transects at each sampling interval. Transects were laid out in the same compass direction in both sampling intervals along the slope contour. Within each belt transect, we identified and tallied all woody plants by species within each transect and measured the basal diameter of all stems $>10 \mathrm{~cm}$ basal diameter by species. 


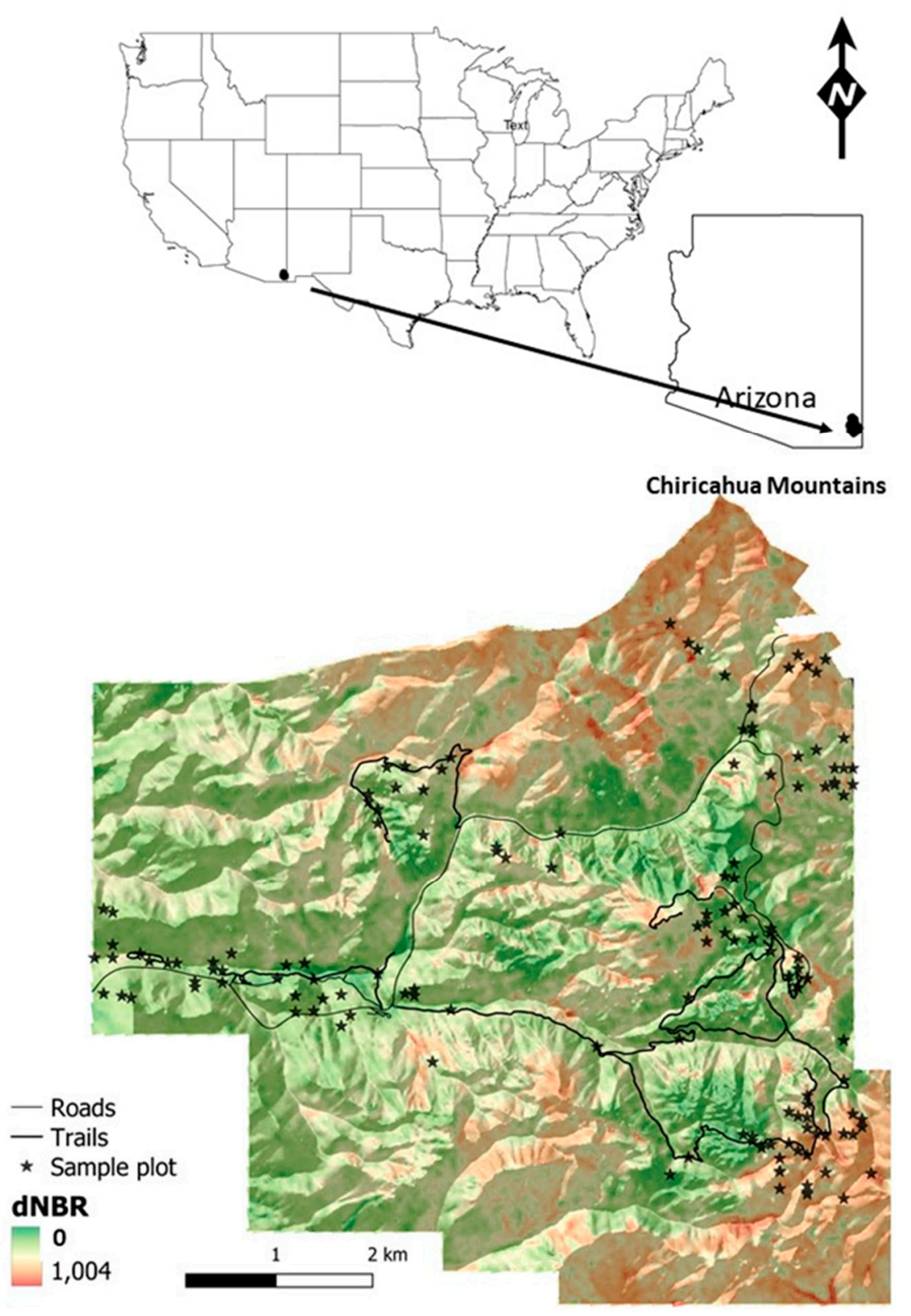

Figure 1. Map of the Chiricahua National Monument, Cochise County, Arizona. Vegetation transect locations are indicated with stars. Plots are overlain on Horseshoe Two Fire differenced normalized burn ratio (dNBR)-derived fire severity data [54].

\subsection{Fire Severity and Topography Data}

We estimated plot fire severity from the Horseshoe Two Fires using raster delta normalized burn ratio (dNBR) data [54] (https:/ / www.mtbs.gov/). dNBR is a Landsat ETM+ derived product that measures absolute change in fire severity that is correlated to the pre-change image. The Normalized Burn Ratio is calculated from ETM+ bands 4 and 7 as (ETM4 - ETM7)/(ETM4 + ETM7), where ETM4 represents the near-infrared spectral range $(0.76-0.90 \mu \mathrm{m})$ and ETM7 represents the shortwave infrared spectral range (2.08-2.35 $\mu \mathrm{m})$. Differenced NBR images (post-fire NBR subtracted from pre-fire NBR) are referred to as dNBR images. We chose to use dNBR rather than other relativized remotely sensed fire severity products because absolute change is a better measure than relative change for our study because it more directly relates to how much vegetation cover change occurred in response to the fire. To account for variation between the plot transect size and 
the 30-m pixel resolution, we smoothed $\mathrm{dNBR}$ via neighborhood mean function with a $3 \times 3$ window in QGIS v3.1.4 [55].

We employed a suite of environmental variables to further investigate the relationships among fire severity, environmental variation, and vegetation change. We recorded the elevation (m), slope (in degrees), topographic position (valley bottom, lower slope, middle slope, upper slope, and ridge top), and slope configuration (concave, concave straight, straight, convex straight, or convex) at the start of each transect, and we then used these variables to calculate topographic relative moisture index (TRMI) [56]. An index of relative site moisture availability based on topographic features, TRMI ranges from xeric to mesic on a scale of 0 to 60 .

\subsection{Statistical Analyses}

\subsubsection{Community Compositional Shifts}

We used nonmetric multidimensional scaling (NMDS) in the vegan package of R [57] to evaluate shifts in woody plant species composition over the sampling interval. Data were woody plant abundance by species in columns and transects in rows with two rows for each plot (i.e., pre- and post-fire). Species-specific changes in abundances from the pre- to post-fire sampling intervals were evaluated using paired t-tests. We examined the contribution of fire severity, TRMI, and elevation in explaining spatial and temporal differences in the woody plant community using Pearson correlation analyses and by plotting the plots in species space with 95th percentile confidence ellipses for the pre- vs. post-fire woody plant community. The influence of topographic position (valley bottom, lower slope, middle slope, or upper slope, or ridgetop) on dNBR was assessed using general linear models with Tukey Honest Significant Difference post-hoc tests. Regression was used to assess the influence of pre-fire forest tree basal area and tree density on wildfire severity. Separate regressions were fit for each model in which pre-fire basal area and density were regressed as predictor variables onto fire severity as a response variable.

We identified the dominant pre-fire vegetation types via hierarchical cluster analysis of the pre-fire woody plant abundance data by species within each vegetation transect. Clustering was performed using Ward's Method (Ward.D), and we determined the optimal number of clusters in the final cluster analysis using the FactoMineR package in R [58]. Dominant species within each cluster were determined using indicator species analysis and the indicspecies package [59]. Finally, we tested for species-specific changes in woody plant abundance within each vegetation type using paired $t$-tests.

\subsubsection{Forest Stand Structural Changes}

We examined differences in live tree stand structure between 2002/3 and 2017/8 for 118 vegetation transects with trees present in the pre-fire sampling interval. Using t-tests, we tested for significant changes in small woody stems (stems $<10 \mathrm{~cm}$ basal diameter) and tree density and basal area over the two sampling intervals. Significant changes were evaluated for all trees and for each tree species, separately. Temporal changes in forest size structure were also evaluated via paired $t$-tests using tree density data per ha by species in 5-cm size classes. Paired t-tests were performed for each tree size class for each of the major tree species within each vegetation type.

The effect of fire severity on woody plant regeneration was evaluated using postfire abundance data for individuals $<10 \mathrm{~cm}$ basal diameter and dNBR for each transect location. We used hurdle regression in the pscl package of $R$ [60] to evaluate the influence of dNBR on post-fire plant regeneration. Hurdle models were employed based on the abundance of zeros in the post-fire dataset for many transects. Initial analyses indicated high overdispersion in the data, which merits the usage of this modeling framework. 


\section{Results}

\subsection{Vegetation Change, Fire Severity, and Topography}

The 3-dimensional nMDS solution, with 95\% percentile confidence ellipses of pre- versus post-fire, revealed a shift from a mixture of trees and shrubs prior to the Horseshoe Two Fire to post-fire prevalence of woody shrubs (Figure 2A, final nMDS model stress $=0.045$ ). This pattern can be explained by the death of many obligate seeder conifers (e.g., P. discolor, $P$. leiophylla), few post-fire seedlings for most of these species, widespread resprouting (e.g., Quercus spp., Mimosa aculeaticarpa), and abundant shrub seedlings (e.g., Arctostaphylos pungens). Paired t-tests corroborated these patterns, and also revealed a significant decline in woody plant densities for nearly all species $(p<0.05$, Table 1$)$.

Table 1. Mean juvenile plant density (stems $<10 \mathrm{~cm}$ basal diameter) and basal area ( $\pm 1 \mathrm{~S}$.E.) for major tree species before $(2002 / 3)$ and after (2017/2018) the Horseshoe Two Fire in Chiricahua National monument, Arizona, USA. Changes in tree density are shown in Table 3 and Figure 4 . The number of plots in which each species occurs is indicated in the $n$ column. Significant differences between the pre- and post-sampling interval according to the Wilcoxon Rank Sign Tests are displayed with asterisks (ns $=$ not significant, ${ }^{*}=p<0.05$, and ${ }^{* *}=p<0.01$ ).

\begin{tabular}{|c|c|c|c|c|c|c|c|c|c|c|}
\hline \multirow{3}{*}{$\begin{array}{c}\text { Species } \\
\text { Hesperocyparis arizonica }\end{array}$} & \multirow{3}{*}{$\begin{array}{l}n \\
26\end{array}$} & \multirow{3}{*}{$\begin{array}{l}\text { year } \\
\text { pre } \\
\text { post }\end{array}$} & \multicolumn{4}{|c|}{ Juvenile Plant Density (\#/ha) } & \multicolumn{4}{|c|}{ Basal Area $\left(\mathrm{m}^{2} / \mathrm{ha}\right)$} \\
\hline & & & 44.3 & \pm & 27.1 & & 2.6 & \pm & 2.2 & \\
\hline & & & 5.8 & \pm & 4.8 & $* *$ & 0.2 & \pm & 0.4 & ** \\
\hline \multirow{2}{*}{ Juniperus deppeana } & \multirow[b]{2}{*}{78} & pre & 20.3 & \pm & 77.8 & \multirow[b]{2}{*}{ ns } & 4.5 & \pm & 8.2 & \multirow[b]{2}{*}{$* *$} \\
\hline & & post & 36.0 & \pm & 103.0 & & 0.4 & \pm & 1.1 & \\
\hline \multirow{2}{*}{ Pinus arizonica } & \multirow{2}{*}{13} & pre & 20.8 & \pm & 11.6 & \multirow{2}{*}{ ns } & 3.0 & \pm & 1.6 & \multirow{2}{*}{ ns } \\
\hline & & post & 0 & \pm & 0 & & 0 & \pm & 0 & \\
\hline \multirow{2}{*}{ Pinus discolor } & \multirow[b]{2}{*}{90} & pre & 165.0 & \pm & 276.0 & \multirow{2}{*}{$* *$} & 2.4 & \pm & 3.9 & \multirow{2}{*}{$* *$} \\
\hline & & post & 23.7 & \pm & 82.0 & & 0.2 & \pm & 1.6 & \\
\hline \multirow{2}{*}{ Pinus edulis } & \multirow{2}{*}{16} & pre & 23.2 & \pm & 100.0 & \multirow{2}{*}{$* *$} & 0.8 & \pm & 2.9 & \multirow{2}{*}{ ** } \\
\hline & & post & 0.0 & \pm & 0.0 & & 0.0 & \pm & 0.0 & \\
\hline \multirow{2}{*}{ Pinus leiophylla } & \multirow[b]{2}{*}{34} & pre & 12.1 & \pm & 43.6 & \multirow[t]{2}{*}{ * } & 1.6 & \pm & 6.0 & \multirow{2}{*}{ ** } \\
\hline & & post & 4.4 & \pm & 23.3 & & 0.0 & \pm & 0.1 & \\
\hline \multirow{2}{*}{ Platanus wrightii } & \multirow{2}{*}{5} & pre & 4.8 & \pm & 7.1 & \multirow{2}{*}{ ns } & 0.2 & \pm & 2.1 & \multirow{2}{*}{ ns } \\
\hline & & post & 2.9 & \pm & 9.5 & & 0.0 & \pm & 0.0 & \\
\hline \multirow{2}{*}{ Pseudotsuga menziesii } & & pre & 10.4 & \pm & 2.2 & & 0.6 & \pm & 2.2 & * \\
\hline & 13 & post & 0.0 & \pm & 0.0 & ns & 0.0 & \pm & 0.0 & * \\
\hline Pinus encolmannii & & pre & 3.1 & \pm & 23.0 & $n c$ & 2.2 & \pm & 8.7 & * \\
\hline Pinus engelmannit & 12 & post & 4.4 & \pm & 34.3 & ns & 0.0 & \pm & 0.2 & ${ }^{*}$ \\
\hline & & pre & 29.9 & \pm & 119.6 & & 4.4 & \pm & 8.0 & \\
\hline Quercus arizonica & 51 & post & 22.0 & \pm & 74.6 & ns & 0.0 & \pm & 0.3 & ** \\
\hline & & pre & 107.9 & \pm & 110.4 & $* *$ & 1.4 & \pm & 4.4 & \\
\hline Quercus emoryi & 36 & post & 9.2 & \pm & 72.8 & $* *$ & 0.0 & \pm & 0.1 & ns \\
\hline & & pre & 176.0 & \pm & 279.8 & & 1.8 & \pm & 6.8 & \\
\hline Quercus hypoleucoldes & 70 & post & 4.0 & \pm & 25.5 & $* *$ & 0.0 & \pm & 0.0 & *** \\
\hline & & pre & 585.6 & \pm & 619.9 & & 29.0 & \pm & 32.4 & \\
\hline TOTAL & & post & 108.1 & \pm & 200.5 & $* *$ & 1.4 & \pm & 5.1 & ** \\
\hline
\end{tabular}

Fire severity, topography, and pre-fire vegetation structure significantly influenced the magnitude of vegetation change (Table 2; Figures 2-4). The nMDS solution and Pearson correlations of species and local environmental variables revealed that fire severity (dNBR) and elevation were significant drivers of vegetation change across nMDS axis 1. Elevation and dNBR were negatively correlated with axis 1 ; they both decreased from left to right along this axis. Soil moisture, as measured by TRMI, was strongly positively correlated with nMDS axes 1 and 2, showing a transition within transects from low to high soil moisture from the bottom to the top of nMDS axis 2 . Fire severity differed significantly by topographic position, whereby mesic valley bottoms with high TRMI burned at significantly lower dNBR than other settings according to a pairwise Tukey's Honest Significant Difference test $(p<0.05)$. Pre-fire forest stand structure also significantly influenced fire severity, with 2002/3 basal area positively influencing Horseshoe Two Fire 
severity, although this effect declined at very high basal area $(p<0.001$; Figure 4$)$. Together, these results suggest that fire severity was higher within heavily stocked stands, and on upper slopes, higher elevations, and drier sites.
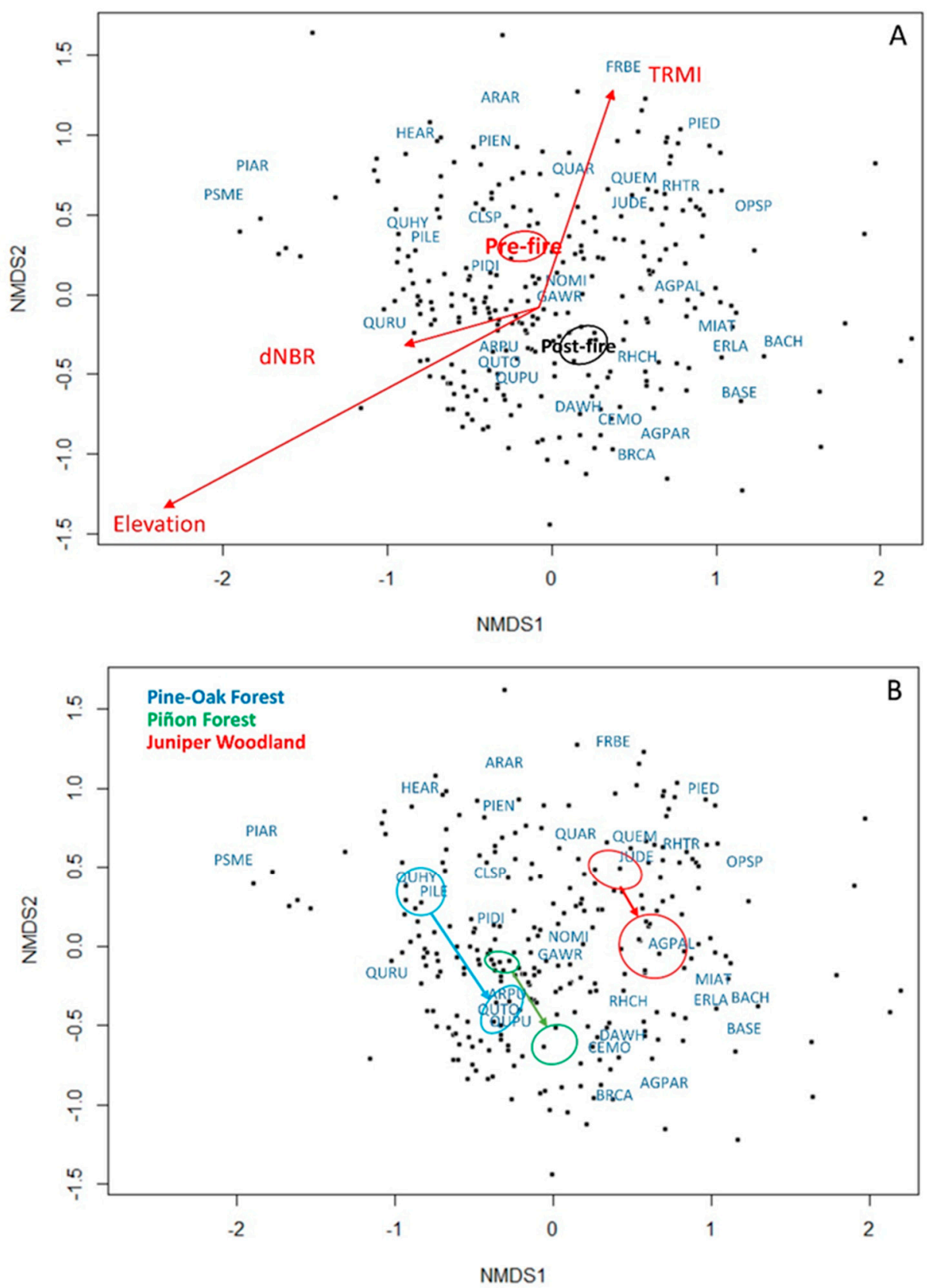

Figure 2. Nonmetric multidimensional scaling of 138 vegetation plots (black dots) in species space with pre- and post-fire vegetation types plotted with 95th percentile confidence ellipses around the centroid of each time-step. (A) Fire severity (dNBR), soil moisture (TRMI), and elevation are all significantly correlated with nMDS axes 1 and $2(p<0.01)$; (B) nMDS plotted with 95th percentile confidence ellipses around the centroid of each vegetation type for each sampling interval. Pines were abundant in the pre-fire sampling interval but were largely killed by the fire. Post-fire transects are characterized by dominance by shrub and resprout oak taxa. Species acronyms are identified in Table 1. 
Table 2. Pearson correlations of species abundance and environmental variables with plot scores for nMDS axes for vegetation transects and environmental variables. Significant species correlations are indicated with asterisks $\left({ }^{*}=p>0.05\right.$, $\left.{ }^{* *}=p>0.01,{ }^{* * *}=p>0.001\right)$.

\begin{tabular}{|c|c|c|c|c|c|c|c|}
\hline Species & Acronym & Lifeform & NMDS1 & NMDS2 & $\mathrm{r}^{2}$ & $P$-Value & Significance \\
\hline Agave palmeri & AGPAL & shrub & 0.967 & 0.256 & 0.064 & 0.001 & $* * *$ \\
\hline Arbutus arizonica & ARAR & tree & -0.273 & 0.962 & 0.055 & 0.001 & $* * *$ \\
\hline Arctostaphylos pungens & ARPU & shrub & -0.972 & -0.236 & 0.141 & 0.001 & $* * *$ \\
\hline Cercocarpus montanus & CEMO & shrub & 0.488 & -0.873 & 0.006 & 0.434 & \\
\hline Daslylironwrightii & DAWH & shrub & 0.652 & -0.759 & 0.034 & 0.004 & $* *$ \\
\hline Frangula betulafolia & FRBE & shrub & 0.225 & 0.974 & 0.020 & 0.061 & \\
\hline Garrya wrightii & GAWR & shrub & 0.014 & 1.000 & 0.007 & 0.352 & \\
\hline Hesperocyparis ariconica & HEAR & tree & -0.522 & 0.853 & 0.141 & 0.001 & $* * *$ \\
\hline Juniperus deppeana & JUDE & tree & 0.433 & 0.901 & 0.342 & 0.001 & $* * *$ \\
\hline Mimosa aculeaticarpa & MIAT & shrub & 0.998 & -0.059 & 0.134 & 0.001 & $* * *$ \\
\hline Nolina microcarpa & NOMI & shrub & 0.042 & 0.999 & 0.023 & 0.061 & \\
\hline Opuntia spinosior & OPSP & shrub & 0.803 & 0.596 & 0.125 & 0.001 & $* * *$ \\
\hline Pinus arizonica & PIAR & tree & -0.890 & 0.455 & 0.175 & 0.001 & $* * *$ \\
\hline Pinus discolor & PIDI & tree & -0.789 & 0.615 & 0.095 & 0.001 & $* * *$ \\
\hline Pinus edulis & PIED & tree & 0.511 & 0.859 & 0.087 & 0.001 & $* * *$ \\
\hline Pinus engelmannii & PIEN & tree & -0.425 & 0.905 & 0.054 & 0.001 & $* * *$ \\
\hline Pinus leiophylla & PILE & tree & -0.787 & 0.617 & 0.087 & 0.001 & $* * *$ \\
\hline Platanus wrightii & PLWR & tree & -0.155 & 0.988 & 0.103 & 0.001 & $* * *$ \\
\hline Prosopis glandulosa & PRGL & shrub & 0.980 & 0.201 & 0.064 & 0.001 & $* * *$ \\
\hline Pseudotsuga menzeisii & PSME & tree & -0.927 & 0.376 & 0.050 & 0.002 & $* *$ \\
\hline Quercus arizonica & QUAR & shrub/tree & 0.049 & 0.999 & 0.178 & 0.001 & $* * *$ \\
\hline Quercus emoryi & QUEM & shrub/tree & 0.468 & 0.884 & 0.088 & 0.001 & $* * *$ \\
\hline Quercus hypoleucoides & QUHY & shrub/tree & -0.818 & 0.576 & 0.348 & 0.001 & $* * *$ \\
\hline Quercus rugosa & QURU & shrub & -0.998 & 0.070 & 0.091 & 0.001 & $* * *$ \\
\hline Quercus toumeyi & QUTO & shrub & -0.795 & -0.606 & 0.065 & 0.001 & $* * *$ \\
\hline Rhus choriophylla & $\mathrm{RHCH}$ & shrub & 0.935 & -0.354 & 0.008 & 0.306 & \\
\hline Rhrus trilobata & RHTR & shrub & 0.539 & 0.843 & 0.054 & 0.002 & $* *$ \\
\hline \multicolumn{8}{|l|}{ Environmental Variables } \\
\hline TRMI & & & 0.30212 & 0.95327 & 0.1599 & 0.001 & $* * *$ \\
\hline dNBR & & & -0.9483 & -0.31738 & 0.0491 & 0.002 & $* *$ \\
\hline Elevation & & & -0.8584 & -0.51298 & 0.4257 & 0.001 & $* * *$ \\
\hline severity & & & & & 0.0257 & 0.031 & * \\
\hline timestep & & & & & 0.1454 & 0.001 & $* * *$ \\
\hline timestep * vegetation type & & & & & 0.4992 & 0.001 & $* * *$ \\
\hline
\end{tabular}

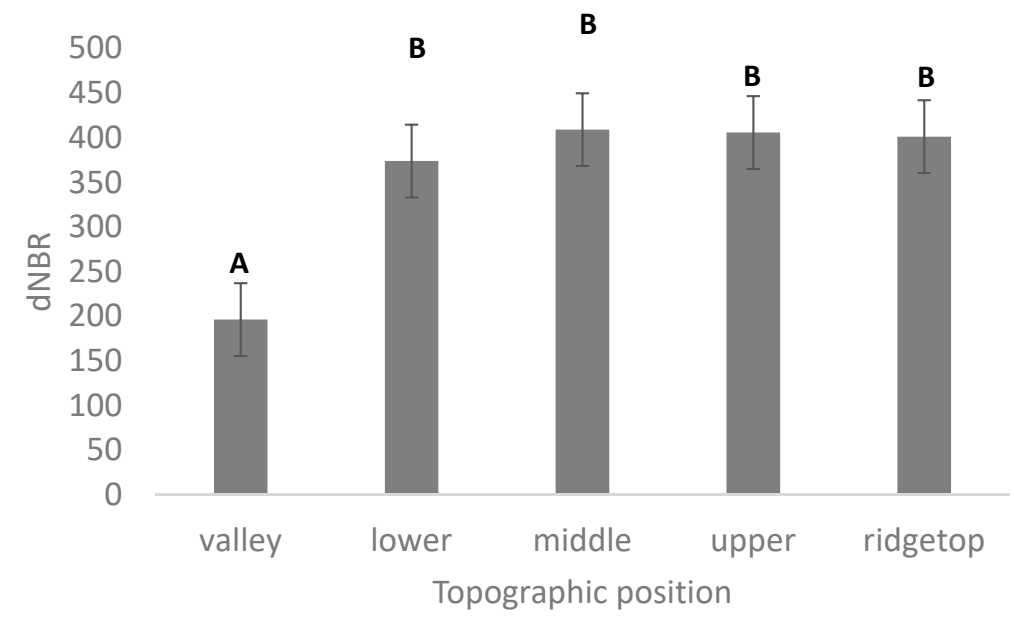

Figure 3. Mean dNBR fire severity (+/ - 1 S.E.) grouped by topographic position: valley $(n=50)$, lower $(n=36)$, middle $(n=30)$, upper $(n=28)$, and ridgetop $(n=38)$ in Chiricahua National Monument, Arizona. Letters indicate significant post-hoc Tukey's pairwise differences in dNBR and TRMI among topographic positions. Bars that do not share a letter differ significantly at $p<0.05$. 


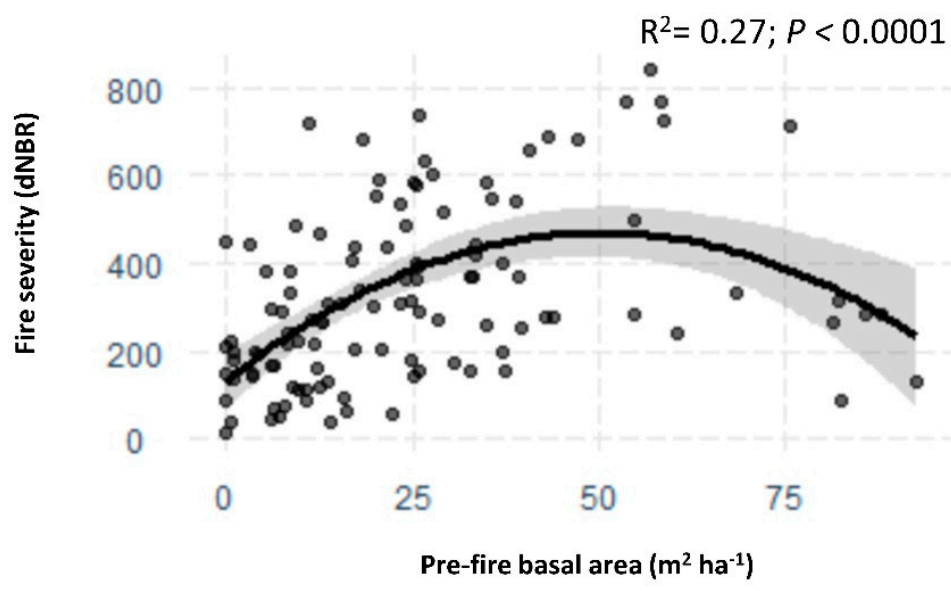

Figure 4. Polynomial regression model results of pre-fire basal area on Horseshoe Two Fire severity (dNBR) influences on stand structural changes in tree basal area from 2002/3 to 2017/18 plotted with $95 \%$ confidence intervals in gray. Pre-fire tree basal area was significant positive influence on fire severity in Chiricahua National Monument.

\subsection{Vegetation Changes by Forest Cover Type}

The cluster analysis of pre-fire vegetation data provided a method for evaluating vegetation changes within the major vegetation types in CHIR. The nbClust function identified three dominant clusters, or vegetation types, prior to the fire including juniper woodlands $(n=59)$, piñon forest $(n=39)$, and pine-oak forest $(n=40)$. The three vegetation types were distributed across the landscape in relation to elevation and soil moisture, and woody plant dominance differed significantly among them according to the indicator species analysis results (Figure 2B; Table 3). Juniper woodlands were distributed across low-elevation, dry sites (Figure 2; Table 2). Significant indicator plants in juniper woodlands included Juniperus deppeana, Quercus emoryi, and Pinus edulis and woody scrub and succulent taxa (Agave palmeri, Mimosa aculeaticarpa, Opuntia spinosior and Prosopis glandulosa) (Table 3). Piñon forests were distributed across middle-elevation sites with intermediate soil moisture. Indicator species within this vegetation type included just one major tree species, Pinus discolor, and a mixture of desert shrub associate species (Arctostaphylos pungens, Dasylirion wheeleri, Garrya wrtightii, Nolina microcarpa and Quercus toumeyi). Finally, pine-oak forests dominated mesic and high elevation sites. Indicator species within the pine-oak forest type were the thick-barked pines (Pinus engelmannii, P. leiophylla and P. arizonica) and oaks (Quercus arizonica and Q. hypoleucoides), as well as several other mesic site specialist trees (Pseudotsuga menziesii and Arbutus arizonica).

The shift in dominance from trees prior to the fire to shrub species after the fire was consistent across all vegetation types, although each vegetation type experienced different changes in species composition. Juniper woodlands experienced the smallest shift in plant community composition (i.e., the smallest distance between pre- and post-fire 95th percentile confidence ellipses), likely because they burned at lower severity than other vegetation types. Even so, this vegetation type shifted away from pre-fire dominance by oaks (Quercus emoryi and Q. arizonica) and junipers (Juniperus deppeana) to a post-fire community consisting mainly of xerophytic shrubs (Garry wrightii, Agave palmeri, Mimosa aculeaticarpa, Dasylirion wheeleri and Nolina microcarpa). Piñon forests experienced moderate to high fire severity, and this vegetation type shifted from a pre-fire species matrix of $P$. discolor, $Q$. toumeyi and A. pungens to a post-fire community of woody shrubs (Dasylirion wheeleri, Cercocarpus montanus, Agave parryi and Dasylirion wheeleri), but virtually no piñon pines (Table 2). Pine-oak forests burned at the highest fire severity of all vegetation types and consequentially experienced the biggest shift in species dominance. Transitions from pre- to post-fire within the pine-oak forest type were manifest by significant declines in 
thick-barked pines and Q. hypoleucoides and increases in scrub oaks (Q. toumeyi and $Q$. rugosa) and manzanita (A. pungens), especially at sites that burned at high fire severity.

Table 3. Indicator species analysis results indicating the fidelity of species occurrence in each of the three major vegetation types in Chiricahua National Monument, Arizona. Indicator values are shown for each species within each vegetation type, which was calculated as the probability of finding the species in samples belonging to that vegetation type.

\begin{tabular}{|c|c|c|c|c|c|}
\hline Species & Acronym & Pine-Oak Forest & Piñon Forest & Juniper Woodland & $\begin{array}{c}\text { Indicator Species } \\
P \text {-Value }\end{array}$ \\
\hline Agave palmeri & AGPAL & 1 & 0.537 & 0.004 & 0.012 \\
\hline Arbutus arizonica & ARAR & 0.012 & 1 & 0.913 & 0.036 \\
\hline Arctostaphylos pungens & ARPU & 0.845 & 0.001 & 1 & 0.003 \\
\hline Dasylirion wheeleri & DAWH & 1 & 0.01 & 0.229 & 0.030 \\
\hline Frangula betulifolia & FRBE & 0.225 & 0.974 & 0.020 & 0.061 \\
\hline Garrya wrightii & GAWR & 0.872 & 0.01 & 0.888 & 0.030 \\
\hline Hesperocyparis arizonica & HEAR & 0.221 & 0.802 & 0.433 & 0.527 \\
\hline Juniperus deppeana & JUDE & 0.99 & 0.996 & 0.001 & 0.003 \\
\hline Mimosa aculeaticarpa & MIAT & 0.994 & 0.994 & 0.001 & 0.003 \\
\hline Nolina microcarpa & NOMI & 1 & 0.001 & 0.652 & 0.003 \\
\hline Opuntia spinosior & OPSP & 0.998 & 1 & 0.001 & 0.003 \\
\hline Pinus arizonica & PIAR & 0.001 & 0.982 & 1 & 0.003 \\
\hline Pinus discolor & PIDI & 0.286 & 0.003 & 1 & 0.009 \\
\hline Pinus edulis & PIED & 0.974 & 1 & 0.001 & 0.003 \\
\hline Pinus engelmannii & PIEN & 0.001 & 1 & 0.956 & 0.003 \\
\hline Pinus leiophylla & PILE & 0.002 & 0.958 & 0.937 & 0.006 \\
\hline Platanus wrightii & PLWR & 0.398 & 1 & 0.186 & 0.461 \\
\hline Prosopis glandulosa & PRGL & 1 & 1 & 0.013 & 0.038 \\
\hline Pseudotsuga menziesii & PSME & 0.004 & 0.98 & 0.914 & 0.012 \\
\hline Quercus arizonica & QUAR & 0.016 & 1 & 0.205 & 0.047 \\
\hline Quercus emoryi & QUEM & 1 & 1 & 0.001 & 0.003 \\
\hline Quercus hypoleucoides & QUHY & 0.001 & 0.996 & 1 & 0.003 \\
\hline Quercus rugosa & QURU & 0.179 & 0.853 & 0.502 & 0.447 \\
\hline Quercus toumeyi & QUTTO & 1 & 0.001 & 1 & 0.003 \\
\hline Rhus choriophylla & $\mathrm{RHCH}$ & 0.953 & 0.102 & 0.512 & 0.276 \\
\hline Rhus trilobata & RHTR & 0.555 & 1 & 0.031 & 0.090 \\
\hline
\end{tabular}

\subsection{Fire Effects on Forest Stand Structure}

We observed a significant decline in seedling abundance, tree density, and basal area across a range of species and tree size classes (Tables 2 and 4; Figure 5), and the hurdle regression modeling revealed that $\mathrm{dNBR}$ had a significant, negative influence on post-fire tree regeneration for all tree species $(p<0.001$, Appendix D). Changes occurred within all three vegetation types and over a variety of size classes, including very large trees $(p<0.05)$ (Figure 5, Appendices A-C). Piñon forest experienced significant declines in all woody plant species' abundances. However, possibly the most dramatic change within this vegetation type was manifest by major declines in P. discolor across virtually all size classes, suggesting widespread mortality of this species. Juniper woodlands similarly experienced significant declines in tree species including Quercus arizonica and Q. emoryi, although this vegetation type maintained substantial $J$. deppeana tree cover after the fire because transects within this vegetation type burned at lower severity. Finally, pine-oak forest, which burned at higher fire severity than the other two vegetation types and displayed significant declines in thick-barked pines across a range of size classes. As in other vegetation types, the residual pine-oak forest post-fire woody plant matrix was also dominated by small-diameter shrub taxa, especially within transects that burned at higher fire severity. 
Table 4. Mean woody plant abundance $\left(\mathrm{ha}^{-1}\right)$ of major woody plant species in transects for pre-fire (2002/2003) and post-fire (2017/2018) in Chiricahua National Monument. Means are shown for all transects and for all vegetation types. Down arrows indicate significant declines in woody plant abundance according to paired $t$-tests at the $\alpha<0.05$-level. Full t-test modeling results and sample sizes are shown in Appendix B.

\begin{tabular}{|c|c|c|c|c|c|c|c|c|c|c|c|c|}
\hline \multirow{2}{*}{ Species } & \multicolumn{2}{|c|}{ All Transects } & & \multicolumn{3}{|c|}{ Juniper Woodland } & \multicolumn{3}{|c|}{ Pine-Oak Forest } & \multicolumn{3}{|c|}{ Piñon Forest } \\
\hline & Pre-Fire & Post-Fire & & Pre-Fire & Post-Fire & & PRE-FIRE & Post-Fire & & Pre-Fire & Post-Fire & \\
\hline Agave palmeri & 26.7 & 13.9 & $\downarrow$ & 60.7 & 25.8 & $\downarrow$ & 3.3 & 2.0 & & 34.6 & 8.2 & \\
\hline Arctostaphylos pungens & 177.4 & 59.4 & $\downarrow$ & 95.1 & 32.5 & $\downarrow$ & 187.9 & 74.0 & $\downarrow$ & 291.5 & 67.7 & $\downarrow$ \\
\hline Dasylirion wheeleri & 39.5 & 11.1 & $\downarrow$ & 43.9 & 16.3 & $\downarrow$ & 1.4 & 2.0 & & 72.2 & 12.3 & $\downarrow$ \\
\hline Garrya wrightii & 38.1 & 10.4 & $\downarrow$ & 27.5 & 10.8 & $\downarrow$ & 32.3 & 2.0 & $\downarrow$ & 60.2 & 18.5 & $\downarrow$ \\
\hline Hesperocyparis arizonica & 99.4 & 6.9 & $\downarrow$ & 94.5 & 9.5 & $\downarrow$ & 142.3 & 4.0 & & 62.8 & 6.2 & \\
\hline Juniperus deppeana & 113.7 & 76.5 .5 & $\downarrow$ & 210.2 & 134.2 & $\downarrow$ & 27.5 & 30.0 & & 56.3 & 36.9 & \\
\hline Mimosa aculeaticarpa & 10.1 & 13.9 & & 22.4 & 27.1 & & 1.3 & 4.0 & & 1.3 & 4.1 & \\
\hline Nolina microcarpa & 180.9 & 30.1 & $\downarrow$ & 170.9 & 25.8 & $\downarrow$ & 103.5 & 22.0 & $\downarrow$ & 275.7 & 45.1 & $\downarrow$ \\
\hline Pinus arizonica & 95.9 & 0 & $\downarrow$ & 0.0 & 0.0 & & 326.9 & 0.0 & $\downarrow$ & 4.1 & 0.0 & \\
\hline Pinus discolor & 253.3 & 44.0 & $\downarrow$ & 221.7 & 5.4 & $\downarrow$ & 155.1 & 44.0 & $\downarrow$ & 402.0 & 102.6 & $\downarrow$ \\
\hline Pinus edulis & 50.3 & 1.7 & $\downarrow$ & 111.7 & 1.4 & & 9.0 & 0.0 & & 0.0 & 4.1 & \\
\hline Pinus engelmannii & 24.1 & 6.3 & & 38.9 & 5.4 & $\downarrow$ & 26.0 & 14.0 & $\downarrow$ & 0.0 & 0.0 & \\
\hline Pinus leiophylla & 45.2 & 9.8 & $\downarrow$ & 38.2 & 9.5 & $\downarrow$ & 81.4 & 16.0 & $\downarrow$ & 18.7 & 4.1 & \\
\hline Pseudotsuga menziesii & 25.5 & 0.0 & & 4.5 & 0.0 & & 80.4 & 0.0 & & 1.3 & 0.0 & \\
\hline Quercus arizonica & 134.2 & 60.2 & $\downarrow$ & 192.3 & 92.2 & $\downarrow$ & 171.3 & 48.0 & & 8.3 & 24.6 & \\
\hline Quercus emoryi & 55.2 & 23.1 & & 125.2 & 48.8 & $\downarrow$ & 1.3 & 2.0 & & 4.7 & 6.2 & \\
\hline Quercus hypoleucoides & 269.9 & 50.4 & $\downarrow$ & 51.6 & 24.4 & $\downarrow$ & 716.3 & 106.0 & $\downarrow$ & 142.3 & 32.8 & $\downarrow$ \\
\hline Quercus rugosa & 28.6 & 16.8 & & 23.3 & 5.4 & & 52.4 & 38.0 & & 12.3 & 12.3 & \\
\hline Quercus toumeyi & 244.5 & 58.5 & $\downarrow$ & 14.1 & 31.2 & $\downarrow$ & 56.7 & 48.0 & & 785.8 & 110.8 & $\downarrow$ \\
\hline
\end{tabular}
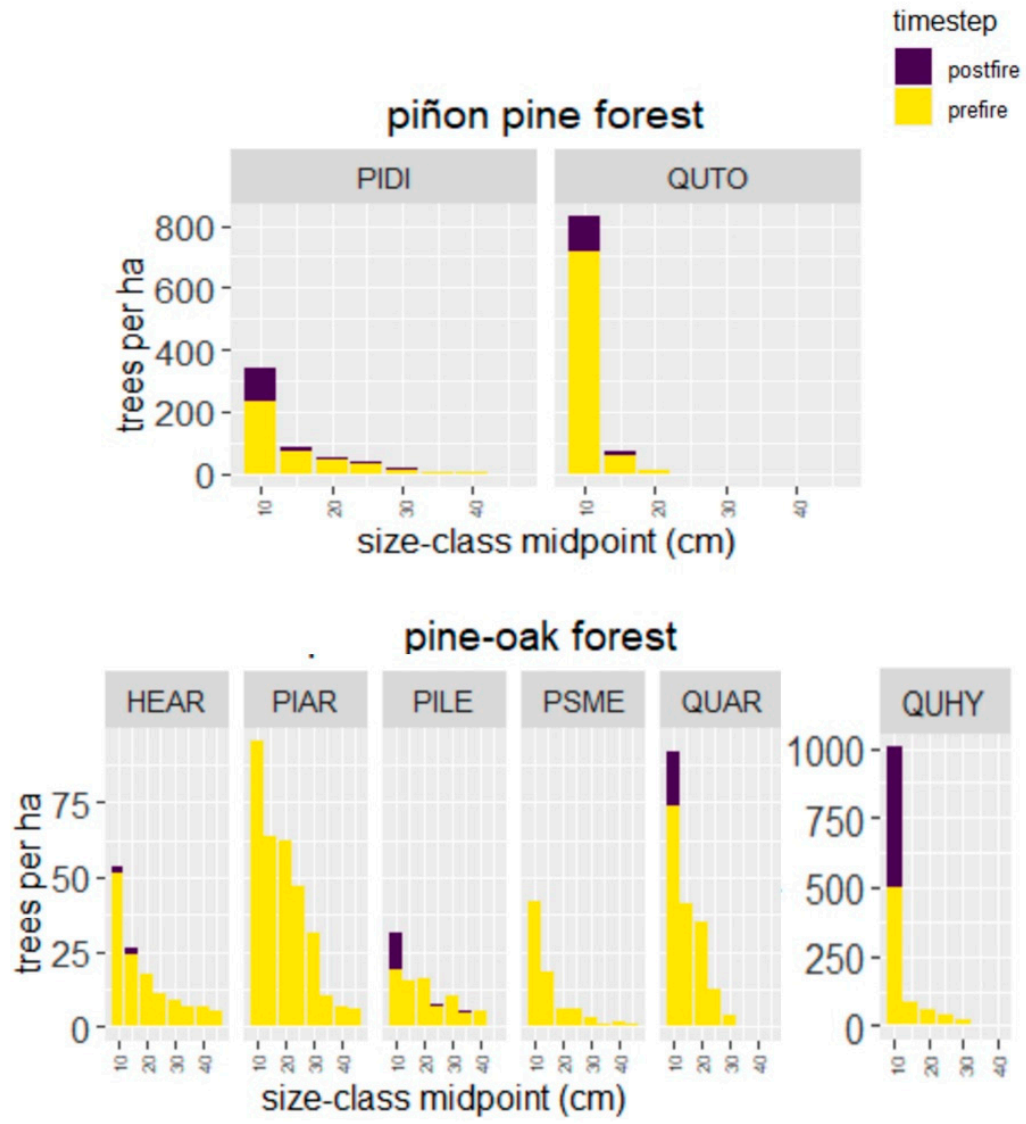

Figure 5. Cont. 


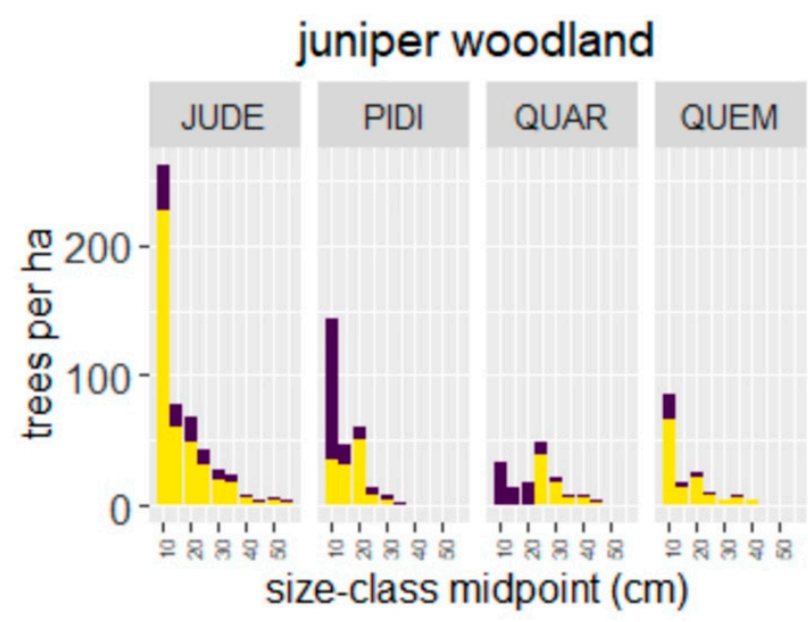

Figure 5. Mean size class distributions $\left(\# \mathrm{ha}^{-1}\right.$ ) in 5-cm size classes for the pre-fire (yellow) and post-fire (purple) samples for dominant tree species in the three major vegetation types in Chiricahua National Monument, Arizona. All tree species experienced significant declines in tree species abundances in size classes $<20 \mathrm{~cm}$ diameter at breast height. Full t-test model results are shown in Appendix C.

\section{Discussion}

The results demonstrate the effects of a contemporary wildfire that burned with mixed effects on Madrean Sky Island vegetation. Fire severity, elevation, and topography regulated the effects of the Horseshoe Two Fire on woody plant community composition and the magnitude of vegetation change over time. While prior research has documented the role of these factors in driving transitions from pine-oak forest to shrubland in the wake of high-severity wildfire [21,33,34,37,61], this study (see also Taylor et al. 2021) is one of the first to document such recent fire effects within drier, more open woody vegetation types in the Sky Islands.

All species and vegetation types in CHIR experienced significant tree mortality across a wide range of size classes with increasing fire severity, low post-fire abundance by obligate seeder species and abundant post-fire dominance by species capable of re-sprouting after fire. This response is consistent with a mounting body of work demonstrating that an increase in the severity, size, and frequency of wildfires often leads to at least a short-term loss of fire-resistant obligate seeder species, across vast regions of the southwestern and western United States spanning the Rocky Mountains [32,62-69], the Sierra Nevada [70,71], the Sky Islands [34,72-74], and the Sierra Madre [75,76]. As in these other studies, the magnitude of change in species abundance and forest stand structure increased with fire severity. Our results also quantify fire-triggered changes in dominance across the full range of woody plant species in CHIR that span diverse vegetation types. Tree regeneration after fire can occur over long timespans; however, the lack of post-fire obligate seeder taxa in CHIR with increasing fire severity over the short-term suggests that continued monitoring is important for understanding Sky Island post-fire successional trajectories.

\subsection{Wildfire Effects on Juniper Woodlands}

While juniper woodlands experienced some shifts in species dominance from trees to shrubs, they largely burned at lower severity than other vegetation types, and J. deppeana abundances did not decline significantly in response to the fire. Juniper forests in CHIR are generally distributed across lower elevations with gentler topography, relative to other forest types, and for this reason, they mostly experienced lower-severity fire. Other studies corroborate this pattern, suggesting that juniper woodland systems are well adapted to low-severity fire characterized by low flame lengths and fire spread rates in these more open woodlands comprised of scattered trees and interspersed grasses [77]. Coupled with the resprouting capacity of co-occurring tree species in juniper woodlands (e.g., J. 
deppeana, Q. emoryi and Q. arizonica), this indicates that juniper woodlands may be capable of rebounding more quickly from contemporary wildfires than other vegetation types in CHIR because recent fires continue to burn at lower severity within these woodlands.

\subsection{Wildfire Effects on Piñon Pine Forest}

Piñon forests experienced a transition from a pre-fire mixture of obligate seeder piñon pines and resprouter shrubs to a post-fire plant community dominated by resprouter shrubs and xerophytic obligate seeders. Fire severity drove this pattern, whereby moderate- and higher-severity sites experienced greater changes than areas that remained unburned or that burned at lower-severity. Pinus discolor was especially hard hit by the wildfire, in both this vegetation type and in juniper woodlands, experiencing substantial declines in abundance across all tree size classes. Changes in woody plant dominance and forest stand structure in piñon forests likely occurred in part as a consequence of 20th and early 21st century tree recruitment and fuel accumulation during the fire suppression era, a pattern found in piñon-juniper woodlands [22]. As demonstrated herein, fire severity increased from low to high basal area for all transects, as well as for plots in piñon forests alone. The decline in severity at the highest basal areas stems from transects in pine-oak forests living within protected valley bottoms, where basal area was high and fire severity was relatively low. Therefore, the fire-induced reduction in basal area and tree densities within sites that experienced low- to moderate-severity fire could be considered a benefit associated with these fires that could also result in lower-severity fires in the future given the strong relationship between basal area and dNBR.

Piñon forests with a continuous shrub or tree canopy layer often burn in infrequent, high-severity, stand-replacing fires [77-80], although more frequent, low-severity fires also occur at some sites $[24,81,82]$. It is therefore no surprise that fire-sensitive and thin-barked $P$. discolor experienced high tree mortality in CHIR when these forests experienced moderateto high-severity fire after almost a century of fire suppression and tree recruitment. Prior age data from within this forest type in CHIR by Baisan and Morino [83] and Taylor, Poulos, Kluber, Issacs, Pawlikowski and Barton [26] and in the eastern Chiricahuas by Barton [44] suggest that $P$. discolor densities increased dramatically during the fire suppression era without frequent fire. The Horseshoe Two Fire may have partially reversed this effect of fire suppression by killing trees that recruited in the absence of fire, especially on lower- to moderate-severity sites. However, within higher-severity areas, this infilling of trees under fire suppression may have had the consequence of increasing fire severity within this forest type during the Horseshoe Two Fire and killing parent seed trees that might have survived lower severity fire.

The extent to which the Horseshoe Two Fire differed from historical fire regimes within the piñon forests of CHIR remains uncertain. Fire-scars are common in certain piñon pine species like P. cembroides that exhibits some degree of self-pruning and thicker bark [24,81]; however, fire scars are rare in other piñons including P. edulis in southern Colorado [80] and P. discolor in the Chiricahua Mountains [25]. Piñon pine age data from Floyd, Hanna, and Romme [80] and Poulos, Reemts, Wogan, Karges, and Gatewood [83] suggest that these two species regenerate in cohorts after stand-replacing wildfires, and that post-fire piñon pine regeneration at CHIR could take decades to centuries. Alternatively, the Horseshoe Two Fire may have simply reversed over a century of tree recruitment that occurred during the fire suppression era.

The current study documents short-term, post-fire woody plant recovery within the first 6-7 years after fire. However, the rate of piñon pine dispersal and recruitment into burn patches may occur over much longer time-scales because piñon dispersal and survival depend upon Mexican jay (Aphelocoma wollweberi) and rodent (e.g., Peromyscus spp.) seed dispersal and caching, microsite availability, and favorable post-fire growing conditions [84]. The lack of vegetation cover and mature trees within post-fire piñon forests may limit current use of this habitat by these seed dispersing animals [85]. Microsite characteristics are also a key influence on seedling survival. The continued recovery 
of resprouter species will increase vegetation cover over time, which might ameliorate local site conditions by creating shade and increasing relative humidity and soil moisture. Successful xerophytic plants in the post-fire environment could serve as nurse plants for promoting piñon pine regeneration success in the coming decades. For example, Barton [47] documented such a nurse-plant effect for Pinus discolor growing under oaks and other species in similar habitat in the eastern part of the Chiricahua Mountains, a pattern observed elsewhere in southwestern piñon pine-dominated forests [86-88]. Xerophytic resprouters and obligate seeders alike may serve this same role in fostering $P$. discolor regeneration in the future, although increasing aridity under climate change may modulate this potential successional trajectory in coming decades.

\subsection{Wildfire Effects on Pine-Oak Forest}

Pine-oak forests likewise experienced significant shifts in forest stand structure and declines in obligate seeder, thick-barked conifer species, and a shift towards woody plant species capable of regenerating after moderate- and high-severity wildfire. As in other parts of the Chiricahua Mountains, resprouter oaks replaced conifers in the wake of the fire, especially at higher fire severities [34]. However, in CHIR pine-oak forest, the obligate seeder, Arctostaphylos pungens, was also a dominant post-fire species due to a long-lived soil seedbank and layering capacity, both of which are well-known adaptations to highseverity fire [89-91]. Arizona cypress (Hesperocyparis arizonica) was the one conifer species that regenerated densely within higher-severity fire sites in CHIR. Although adults of this species experienced widespread mortality in response to the Horseshoe Two Fire, the serotinous cones of this obligate seeder conifer resulted in high seedling regeneration within the valley bottom habitats where this species thrives [92].

The steep topo-climatic gradients in CHIR promote spatiotemporal heterogeneity in wildfire behavior in both the historical and contemporary fire eras. While pine-oak forests experienced the highest fire severity in CHIR during the Horseshoe Two Fire, topography played an important role in regulating wildfire effects within this forest type. Mesic, valley bottom pine-oak forests generally burned as lower-severity surface fires, just like they did for centuries prior to the removal of fire in the late 1880s. In contrast, pine-oak forests on drier sites, mid-slopes, and upper topographic positions burned at higher fire severity. Similar forests at even higher elevation in the Chiricahuas exhibited mixed severity historic fire regimes [25,93], but fewer fire history records exist for pine-oak forest outside of canyons at intermediate elevations that would allow comparison of the Horseshoe Two Fire to historical fires within these pine-oak forest sites. Some of the fires in the past in these areas may well have burned at moderate to high fire severity, as they ran up the steep slopes of CHIR, especially during fire years that coincided with extreme regional drought.

As in the piñon forests of CHIR, post-fire recruitment of obligate seeders in pine-oak forests also depends on the presence of a parent seed source $[38,84,94]$. The numerous large, moderate- to high-severity patches that burned the landscape could present a barrier to obligate seeder regeneration because of a lack of nearby parent seed sources [95-98] because the relationship between distance to parent tree seed sources and early post-fire seedling recruitment can be predictive of the scale of seedling regeneration success $[84,95,99]$. Valley bottom gallery forests that were spared by the fire or that burned at lower-severity may represent important fire refugia for obligate seeder trees [100]. Such fire refugia can provide a source for forest recovery in adjacent higher-severity fire patches, providing crucial ecological value in an increasingly fiery and warmer world [5,101,102].

\section{Conclusions}

Understanding contemporary wildfire effects on Madrean Sky Island ecosystems is paramount for their long-term conservation in a world that will likely be characterized by more frequent and larger fires in the Anthropocene. This paper documents the landscape-scale effects of a recent megafire on woody plants across a diverse set of vegetation types. Our results reinforce the widely documented loss of obligate seeder conifer 
species moderate to high-severity fire, which has become a serious concern in part because we have insufficient information about long-term conifer re-establishment and recovery after high-severity wildfire. Many view the recent fire-induced shifts from forests to shrublands as a transition to an alternative stable state that is better adapted to the drier, more fire-prone contemporary conditions [36,84]. However, forests and woodlands can also take decades-to-centuries to recover from fire because of spatial and temporal variation in post-fire seed production, and appropriate conditions for pollination, seed production, seedling establishment, and growth to maturity. Post-fire shrublands in CHIR may lack the conditions to support the recovery of the full suite of pre-fire plant species after fire, but the possibility that recovery may just take time cannot be ruled out [103].

The regeneration of obligate seeder tree species may also be threatened by increasing drought under climate change. Most projections indicate that western North America will experience increasing aridity, moisture-deficits, and larger and more frequent wildfires [104-108], a trajectory that would continue trends over the past three decades. More frequent and longer-duration droughts may hinder obligate seeder regeneration, even if seed sources are nearby $[109,110]$. Landscape simulation models suggest that fire-climate interactions will intensify over the coming decades, and that shrubland communities will probably remain a persistent landscape feature well into the future. The wildfire-driven conversion of forest to shrublands is therefore unlikely to abate in coming decades. Accordingly, resprouting capacity and desiccation tolerance will likely play critical roles in shaping post-fire plant communities under future environmental change.

Our results also reveal substantial differences among Madrean vegetation types in their dynamics with respect to fire suppression and the Horseshoe Two Fire. Whereas the Horseshoe Two Fire caused a historic shift in pine-oak forest away from the complex historic mixed-conifer and oak forests found before pre-Euro-American settlement, the other two vegetation types did not exhibit such striking departures from the past. Changes in juniper woodlands were far less than for the other two vegetation types, both because of the lower fire severity (a result of the typically gentler topography where this plant community occurs) and the prevalence of resprouting species. Similar to pine-oak forest, in piñon forest, there was a major shift from an obligate seeder conifer (Pinus discolor) in $2002 / 3$ to mostly scrub taxa in $2017 / 8$. In contrast to pine-oak forest, however, this pattern may have parallels with historic forest dynamics with infrequent stand-replacing fires and may be undoing some of the effects of fire suppression. The contrast between the two vegetation types reminds us of the importance of historic ecological context when evaluating current impacts of fire.

To maintain the diverse species and vegetation matrix of Sky Island forests and woodlands, obligate seeder restoration through enrichment planting by managers may be necessary to re-populate these species in severely burned areas if the management goal is to maintain the diverse pre-fire species matrix. Assisted migration of drought-tolerant Mexican pines from the south, such as P. cembroides, P. durangenis and P. lumholtzii, may also facilitate the long-term persistence of pine forests throughout the Sky Islands region under increasing prevalence of fire and severe drought. Clearly, the soil moisture needs of obligate seeders in this region relative to more drought tolerant woody plants suggest that restoration activities could be more successful in refugial sites with higher moisture levels and lower probability of severe fire and in years with high precipitation. Regardless, continued biological monitoring is needed for understanding the changing nature of forest recovery over time after contemporary wildfires.

Author Contributions: H.M.P. and A.M.B. conceptualized the study and performed the vegetation surveys. M.R.F. and A.H.T. assisted with the field data collection. H.M.P. and M.R.F. performed the statistical analyses and were responsible for writing the first draft of this manuscript. A.M.B. and A.H.T. assisted with reviewing and editing the manuscript in preparation for review. H.M.P., A.M.B. and A.H.T. were responsible for acquiring funding for the study. All authors have read and agreed to the published version of the manuscript. 
Funding: Funding for this study was graciously provided through Western National Parks Association (2017), a task agreement with the University of Maine at Farmington and The National Park Service (Task Agreement no. P17AC00940), a USDI cooperative agreements between The National Park Service and Pennsylvania State University (CA4000-8-9028), and Wesleyan University's Robert Schumann Institute of the College of the Environment.

Data Availability Statement: Data from this study are available at: Helen Poulos. 2021. Chiricahua National Monument Horseshoe Two Fire vegetation data. Knowledge Network for Biocomplexity. doi:10.5063/F1W37TR0.

Acknowledgments: We greatly appreciate the resources management staff at Chiricahua National Monument, and especially Resources Management Chiefs Allan Whalon and Mike Holt, Biologist Helen Fitting, and Fire Management Officer Carrie Dennett for their logistical support for this project. We also thank Isaiah McFarlane, Hunter Vannier, Wyatt McCurdy, Michael Donnelly, Tom Saladyga, Tom Nagel, and Beth Auman for their assistance in the vegetation sampling effort for this study.

Conflicts of Interest: The authors declare no conflict of interest. The funders had no role in the design of the study; in the collection, analyses, or interpretation of data; in the writing of the manuscript, or in the decision to publish the results.

\section{Appendix A}

Table A1. Paired $t$-test significance table evaluating changes in woody plant species abundances over all sample plots, and for major species within each vegetation type in Chiricahua National Monument, Arizona, USA. The majority of woody plant species declined in abundance over the sampling interval.

\begin{tabular}{|c|c|c|c|c|c|c|c|c|c|c|c|c|}
\hline \multirow{2}{*}{ Species } & \multicolumn{3}{|c|}{ All Plots } & \multicolumn{3}{|c|}{ Juniper Woodland } & \multicolumn{3}{|c|}{ Pine-Oak Forest } & \multicolumn{3}{|c|}{ Piñon Forest } \\
\hline & $\mathbf{t}$ & df & $p$-Value & $\mathbf{t}$ & df & $p$-Value & $\mathbf{t}$ & df & $p$-Value & $\mathbf{t}$ & df & $p$-Value \\
\hline Agave palmeri & -2.45 & 30 & 0.014 & -1.79 & 16 & 0.075 & & & & -2.2 & 13 & 0.03 \\
\hline Arctostaphylos pungens & -8.37 & 90 & $<0.001$ & -3.39 & 29 & $<0.001$ & -4.06 & 25 & $<0.001$ & -10.1 & 36 & $<0.001$ \\
\hline Dasylirion wheeleri & -3.22 & 27 & $<0.001$ & -1.99 & 12 & 0.048 & & & & -2.73 & 14 & 0.007 \\
\hline Garrya wrightii & -4.42 & 45 & $<0.001$ & -1.83 & 15 & 0.069 & -2.71 & 10 & 0.008 & -3.32 & 20 & 0.001 \\
\hline Hesperocyparis arizonica & -3.68 & 29 & $<0.001$ & -1.91 & 6 & 0.058 & & & & & & \\
\hline Juniperus deppeana & -1.92 & 78 & 0.054 & -1.96 & 46 & 0.051 & 0.22 & 11 & 0.823 & -1.13 & 21 & 0.264 \\
\hline Mimosia aculeiticarpa & -8.45 & 18 & $<0.001$ & 0.93 & 16 & 0.352 & & & & & & \\
\hline Nolina microcarpa & -3.02 & 8 & $<0.001$ & -8.45 & 34 & $<0.001$ & -2.59 & 18 & 0.011 & -1.14 & 32 & 0.19 \\
\hline Pinus arizonica & -3.11 & 13 & 0.002 & & & & -3.34 & 12 & 0.001 & & & \\
\hline Pinus discolor & -3.4 & 90 & $<0.001$ & -6.68 & 14 & $<0.001$ & -3.2 & 24 & 0.001 & -6.04 & 37 & $<0.001$ \\
\hline Pinus engelmanii & -1.94 & 12 & 0.052 & -3.4 & 7 & 0.052 & -0.81 & 5 & 0.42 & & & \\
\hline Pinus edulis & -3.4 & 18 & $<0.001$ & -3.52 & 14 & $<0.001$ & & & & & & \\
\hline Pinus leiophylla & -3.14 & 34 & 0.001 & -3.14 & 9 & 0.001 & -3.06 & 18 & 0.003 & & & \\
\hline Pseudotsuga menziesii & -1.5 & 13 & 0.133 & & & & -1.38 & 11 & 0.168 & & & \\
\hline Quercus arizonica & -2.92 & 51 & 0.003 & -2.92 & 39 & 0.003 & -1.83 & 10 & 0.07 & & & \\
\hline Quercus emoryi & -1.92 & 36 & 0.055 & -1.92 & 33 & 0.055 & & & & & & \\
\hline Quercus hypoleucoides & -6.11 & 70 & $<0.001$ & -6.11 & 10 & $<0.001$ & -7.62 & 40 & $<0.001$ & -3.35 & 20 & $<0.001$ \\
\hline Quercus rugosa & -1.04 & 22 & 0.296 & & & & -0.83 & 14 & 0.409 & & & \\
\hline Quercus toumeyi & -5.44 & 61 & $<0.001$ & -5.44 & 7 & $<0.001$ & & & & -11.8 & 39 & $<0.001$ \\
\hline
\end{tabular}

\section{Appendix B}

Table A2. Species Latin names, acronyms, and adaptations and responses to fire of common trees and shrubs in Chiricahua National Monument (Sources: USDA Fire Effects Information System; Barton 1999, 2002; Gebow 2005; Barton and Poulos 2018).

\begin{tabular}{|c|c|c|}
\hline PLANT SPECIES & Acronym & Adaptations \& Reponses to Fire \\
\hline \multicolumn{3}{|l|}{ TREES } \\
\hline $\begin{array}{l}\text { Arziona Madrone } \\
\text { (Arbutus arizonica) }\end{array}$ & ARAR & $\begin{array}{l}\text { Variable trunk damage } \\
\text { Can survive extensive bark and cambium damage } \\
\text { Sprouting from the root crown and tree bole }\end{array}$ \\
\hline $\begin{array}{c}\text { Arizona Cypress } \\
\text { (Hesperocyparis arizonica) }\end{array}$ & HEAR & $\begin{array}{l}\text { Fire-sensitive trunk } \\
\text { Serotinous cones }\end{array}$ \\
\hline $\begin{array}{l}\text { Alligator-bark Juniper } \\
\text { (Juniperus deppeana) }\end{array}$ & JUDE & $\begin{array}{l}\text { Large individuals can survive low-severity fire } \\
\text { Sprouting from root crown, trunk, and branches }\end{array}$ \\
\hline $\begin{array}{l}\text { Arizona Pine } \\
\text { (Pinus arizonica) }\end{array}$ & PIAR & Can survive low- and moderate-severity fire \\
\hline
\end{tabular}


Table A2. Cont.

\begin{tabular}{|c|c|c|}
\hline PLANT SPECIES & Acronym & Adaptations \& Reponses to Fire \\
\hline $\begin{array}{l}\text { Border Piñon } \\
\text { (Pinus discolor) }\end{array}$ & PIDI & $\begin{array}{l}\text { Thin bark, fire sensitive } \\
\text { Seeds germinate from seeds cached by animals } \\
\text { Nurse plants facilitate establishment in the open }\end{array}$ \\
\hline $\begin{array}{l}\text { Rocky Mountain Piñon } \\
\quad \text { (Pinus edulis) }\end{array}$ & PIED & $\begin{array}{l}\text { Thin barked fire-sensitive trunk } \\
\text { Seeds germinate from seeds cached by animals }\end{array}$ \\
\hline $\begin{array}{l}\text { Apache Pine } \\
\text { (Pinus englemannii) }\end{array}$ & PIEN & Thicker bark and deeper roots, mature trees are fire resistant \\
\hline $\begin{array}{l}\text { Chihuahua Pine } \\
\text { (Pinus leiophylla) }\end{array}$ & PILE & $\begin{array}{c}\text { Thick bark, can survive low- and moderate-severity fire } \\
\text { Modest sprouting, mainly in small stems } \\
\text { Semi-serotinous cones }\end{array}$ \\
\hline $\begin{array}{c}\text { Douglas-fir } \\
\text { (Pseudotsuga menziesii) }\end{array}$ & PSME & $\begin{array}{c}\text { Can survive low-severity fire; moderate severity in large trees } \\
\text { Susceptible to fire crowning due to low branches }\end{array}$ \\
\hline $\begin{array}{l}\text { Arizona White Oak } \\
\text { (Quercus arizonica) }\end{array}$ & QUAR & $\begin{array}{c}\text { Large individuals can survive low-severity fire } \\
\text { Sprouting after top-kill }\end{array}$ \\
\hline $\begin{array}{l}\text { Emory Oak } \\
\text { (Quercus emoryi) }\end{array}$ & QUEM & $\begin{array}{l}\text { Fire-sensitive trunk } \\
\text { Sprouting after top-kill }\end{array}$ \\
\hline $\begin{array}{l}\text { Gambel Oak } \\
\text { (Quercus gambelii) }\end{array}$ & QUGA & $\begin{array}{l}\text { Sprouting after top-kill from root crown and roots } \\
\text { Large individuals can survive low-severity fire }\end{array}$ \\
\hline $\begin{array}{c}\text { Silverleaf Oak } \\
\text { (Quercus hypoleucoides) }\end{array}$ & QUHY & $\begin{array}{l}\text { Fire-sensitive trunk, but } \\
\text { Large individuals can survive low-severity fire } \\
\text { Sprouting after top-kill }\end{array}$ \\
\hline $\begin{array}{l}\text { Southwestern Black Cherry (Prunus } \\
\text { serotina var. virens) }\end{array}$ & PRSE & $\begin{array}{c}\text { Fire-sensitive trunk } \\
\text { Dormant seed banks stimulated by fire-created openings }\end{array}$ \\
\hline $\begin{array}{l}\text { White fir } \\
\text { (Abies concolor) }\end{array}$ & $\mathrm{ABCO}$ & Fire-sensitive trunk \\
\hline SHRUBS & & Shrubs exhibit low shoot survival of fire \\
\hline $\begin{array}{c}\text { Netleaf Oak } \\
\text { (Quercus rugosa) }\end{array}$ & QURU & Sprouting after top-kill from root crown \\
\hline $\begin{array}{l}\text { Toumey Oak } \\
\text { (Quercus toumeyi) }\end{array}$ & QUTO & Sprouting after top-kill from root crown \\
\hline Pungent Oak (Quercus pungens) & QUPU & Sprouting after top-kill from root crown \\
\hline $\begin{array}{l}\text { Pointleaf Manzanita } \\
\text { (Arctostaphylos pungens) }\end{array}$ & ARPU & $\begin{array}{l}\text { Obligate seeder } \\
\text { Dormant seed banks stimulated by fire } \\
\text { Rooting of low branches observed }\end{array}$ \\
\hline $\begin{array}{l}\text { Mimosa catclaw (Mimosa } \\
\text { aculeiticarpa var. biuncifera) }\end{array}$ & MIBI & $\begin{array}{l}\text { Sprout from the root crown following top-kill } \\
\text { by fire }\end{array}$ \\
\hline $\begin{array}{l}\text { Wright's Silktassel } \\
\text { (Garrya wrightii) }\end{array}$ & GAWR & Sprouting from root crown \\
\hline $\begin{array}{l}\text { Catclaw } \\
\text { (Acacia greggii) }\end{array}$ & ACGR & Sprouting from root crown \\
\hline $\begin{array}{l}\text { Birchleaf Buckthorn } \\
\text { (Frangula betulifolia) }\end{array}$ & FRBE & Sprouting from root crown \\
\hline Sotol (Dasylirion wheeleri) & DAWH & $\begin{array}{c}\text { moderately sensitive to fire; survivor species capable of sprouting } \\
\text { from an aboveground caudex }\end{array}$ \\
\hline $\begin{array}{l}\text { Skunkbush and } \\
\text { (Rhus trilobata) }\end{array}$ & RHTR & $\begin{array}{c}\text { Sprouting } \\
\text { Possible dormant seed bank }\end{array}$ \\
\hline $\begin{array}{l}\text { Littleleaf Sumac } \\
\text { (Rhus microphylla) }\end{array}$ & RHMI & $\begin{array}{c}\text { Sprouting } \\
\text { Possible dormant seed bank }\end{array}$ \\
\hline $\begin{array}{l}\text { Mesquite } \\
\text { (Prosopis glandulosa) }\end{array}$ & PRGL & Sprouting after top-kill from underground stem \\
\hline $\begin{array}{l}\text { Fendler's Ceanothus } \\
\text { (Ceanothus fendleri) }\end{array}$ & CEFE & $\begin{array}{l}\text { Sprouting after top-kill from root crown } \\
\text { Extensive seedling establishment after fire }\end{array}$ \\
\hline $\begin{array}{l}\text { Mountain-mahogany } \\
\text { (Cercocarpus montanus) }\end{array}$ & CEMO & Sprouting after top-kill from root crown \\
\hline Mountain yucca (Yucca madrensis) & YUMA & Sprouting after top-kill from roots \\
\hline
\end{tabular}




\section{Appendix C}

Table A3. Paired $t$-test significance table evaluating changes in the size structure of dominant tree species within each vegetation type in Chiricahua National Monument, Arizona, USA.

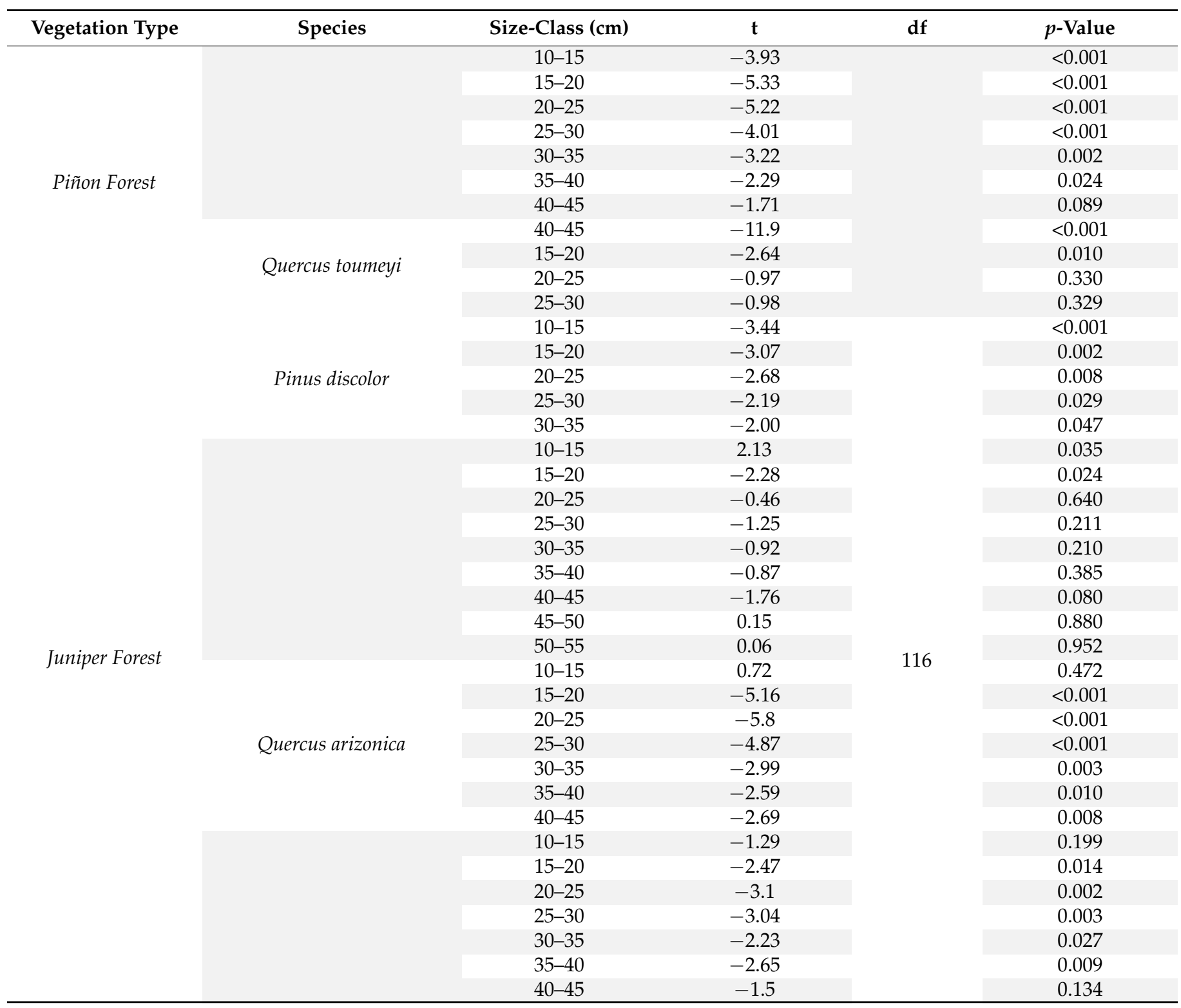


Table A3. Cont.

\begin{tabular}{|c|c|c|c|c|c|}
\hline Vegetation Type & Species & Size-Class (cm) & $\mathbf{t}$ & df & $p$-Value \\
\hline \multirow{38}{*}{ Pine-Oak Forest } & \multirow{20}{*}{ Hesperocyparis arizonica } & $10-15$ & -1.79 & \multirow{38}{*}{78} & 0.077 \\
\hline & & $15-20$ & -2.4 & & 0.018 \\
\hline & & $20-25$ & -2.36 & & 0.020 \\
\hline & & $25-30$ & -1.9 & & 0.059 \\
\hline & & $30-35$ & -2.22 & & 0.029 \\
\hline & & $35-40$ & -1.84 & & 0.068 \\
\hline & & $40-45$ & -1.5 & & 0.135 \\
\hline & & $10-15$ & -2.12 & & 0.036 \\
\hline & & $15-20$ & -3.36 & & 0.001 \\
\hline & & $20-25$ & -3.31 & & 0.001 \\
\hline & & $25-30$ & -3.06 & & 0.002 \\
\hline & & $30-35$ & -2.83 & & 0.005 \\
\hline & & $35-40$ & -2.18 & & 0.031 \\
\hline & & $40-45$ & -1.74 & & 0.084 \\
\hline & & $50-55$ & -1.36 & & 0.175 \\
\hline & & $10-15$ & 0.847 & & 0.399 \\
\hline & & $15-20$ & -1.43 & & 0.156 \\
\hline & & $20-25$ & -1.432 & & 0.155 \\
\hline & & $25-30$ & -1.98 & & 0.050 \\
\hline & & 30-35 & -1.73 & & 0.086 \\
\hline & \multirow{11}{*}{ Pinus leiophylla } & $10-15$ & -0.81 & & 0.415 \\
\hline & & $15-20$ & -2.17 & & 0.033 \\
\hline & & $20-25$ & -2.69 & & 0.008 \\
\hline & & $25-30$ & -2 & & 0.048 \\
\hline & & $30-35$ & -1.69 & & 0.093 \\
\hline & & $35-40$ & -2.05 & & 0.043 \\
\hline & & $45-50$ & -1.68 & & 0.096 \\
\hline & & $50-55$ & -1 & & 0.320 \\
\hline & & $10-15$ & -1.45 & & 0.148 \\
\hline & & $15-20$ & -1.91 & & 0.059 \\
\hline & & $20-25$ & -2.78 & & 0.006 \\
\hline & \multirow{7}{*}{ Quercus arizonica } & $25-30$ & -2.13 & & 0.036 \\
\hline & & $30-35$ & -1.31 & & 0.193 \\
\hline & & $10-15$ & -8.7 & & $<0.001$ \\
\hline & & $15-20$ & -3.01 & & 0.003 \\
\hline & & $20-25$ & -2.94 & & 0.004 \\
\hline & & $25-30$ & -3.23 & & 0.001 \\
\hline & & $30-35$ & -2.11 & & 0.037 \\
\hline
\end{tabular}

\section{Appendix D}

Table A4. Hurdle regression model results for fire severity-post-fire woody plant regeneration in Chiricahua National Monument, Arizona, USA. Post-fire regeneration was significantly negatively influenced by fire severity (dNBR) for all species lumped (shown below), and for individual tree species (data not shown) @ $p<0.001$.

\begin{tabular}{ccccc}
\hline Model & Estimate & Standard Error & z-Value & $\boldsymbol{P}$ \\
\hline (Intercept) & 2.51 & 0.47 & 5.40 & $<0.001$ \\
dNBR & -0.01 & 0.00 & -5.79 & $<0.001$ \\
\hline
\end{tabular}

\section{References}

1. Bond, W.J.; Keeley, J.E. Fire as a global 'herbivore': The ecology and evolution of flammable ecosystems. Trends Ecol. Evol. 2005, 20, 387-394. [CrossRef]

2. He, T.; Lamont, B.B.; Pausas, J.G. Fire as a key driver of Earth's biodiversity. Biol. Rev. 2019, 94, 1983-2010. [CrossRef] [PubMed]

3. Pausas, J.G.; Ribeiro, E. The global fire-productivity relationship. Glob. Ecol. Biogeogr. 2013, 22, 728-736. [CrossRef] 
4. McLaughlin, B.C.; Blakey, R.; Weitz, A.P.; Feng, X.; Brown, B.J.; Ackerly, D.D.; Dawson, T.E.; Thompson, S.E. Weather underground: Subsurface hydrologic processes mediate tree vulnerability to extreme climatic drought. Glob. Chang. Biol. 2020, 26, 3091-3107. [CrossRef] [PubMed]

5. Kolden, C.A.; Bleeker, T.; Smith, A.; Poulos, H.M.; Camp, A.E. Fire Effects on Historical Wildfire Refugia in Contemporary Wildfires. Forests 2017, 8, 400. [CrossRef]

6. Enright, N.; Keith, D.A.; Clarke, M.F.; Miller, B.P. Fire regimes in Australian sclerophyllous shrubby ecosystems: Heathlands, heathy woodlands and mallee woodlands. In Flammable Australia: Fire Regimes and Biodiversity in a Changing World; CSIRO Publishing: Melbourne, Australia, 2012; pp. 215-235.

7. Gonzalez, M.E.; Veblen, T.T.; Sibold, J.S. Influence of fire severity on stand development of Araucaria araucana-Nothofagus pumilio stands in the Andean cordillera of south-central Chile. Austral Ecol. 2010, 35, 597-615. [CrossRef]

8. Fulé, P.Z.; Crouse, J.E.; Heinlein, T.A.; Moore, M.M.; Covington, W.W.; Verkamp, G. Mixed-severity fire regime in a high-elevation forest of Grand Canyon, Arizona, USA. Landsc. Ecol. 2003, 18, 465-486. [CrossRef]

9. Cohn, J.S.; Di Stefano, J.; Christie, F.; Cheers, G.; York, A. How do heterogeneity in vegetation types and post-fire age-classes contribute to plant diversity at the landscape scale? For. Ecol. Manag. 2015, 346, 22-30. [CrossRef]

10. Parr, C.L.; Andersen, A.N. Patch mosaic burning for biodiversity conservation: A critique of the pyrodiversity paradigm. Conserv. Biol. 2006, 20, 1610-1619. [CrossRef]

11. Clarke, P.J.; Lawes, M.J.; Murphy, B.P.; Russell-Smith, J.; Nano, C.E.M.; Bradstock, R.; Enright, N.J.; Fontaine, J.B.; Gosper, C.R.; Radford, I.; et al. A synthesis of postfire recovery traits of woody plants in Australian ecosystems. Sci. Total Environ. 2015, 534, 31-42. [CrossRef]

12. He, T.; Lamont, B.B. Baptism by fire: The pivotal role of ancient conflagrations in evolution of the Earth's flora. Natl. Sci. Rev. 2018, 5, 237-254. [CrossRef]

13. Lamont, B.B.; Enright, N.J.; He, T. Fitness and evolution of resprouters in relation to fire. Plant Ecol. 2011, $212,1945-1957$. [CrossRef]

14. Krawchuk, M.A.; Haire, S.L.; Coop, J.; Parisien, M.A.; Whitman, E.; Chong, G.; Miller, C. Topographic and fire weather controls of fire refugia in forested ecosystems of northwestern North America. Ecosphere 2016, 7, e01632. [CrossRef]

15. Archibald, S.; Lehmann, C.E.; Belcher, C.; Bond, W.J.; Bradstock, R.A.; Daniau, A.; Dexter, K.; Forrestel, E.; Greve, M.; He, T. Biological and geophysical feedbacks with fire in the Earth system. Environ. Res. Lett. 2018, 13, 033003. [CrossRef]

16. Poulos, H.M.; Taylor, A.H.; Beaty, R.M. Environmental controls on dominance and diversity of woody plant species in a Madrean, Sky Island ecosystem, Arizona, USA. Plant Ecol. 2007, 193, 15-30. [CrossRef]

17. Poulos, H.M.; Camp, A.E. Topographic influences on vegetation mosaics and tree diversity in the Chihuahuan Desert Borderlands. Ecology 2010, 91, 1140-1151. [CrossRef]

18. Coblentz, D.D.; Riitters, K.H. Topographic controls on the regional-scale biodiversity of the south-western USA. J. Biogeogr. 2004, 31, 1125-1138. [CrossRef]

19. Van Devender, T.R.; Avila-Villegas, S.; Emerson, M.; Turner, D.; Flesch, A.D.; Deyo, N.S. Biodiversity in the Madrean Archipelago of Sonora, Mexico. In Proceedings of the Merging Science and Management in a Rapidly Changing World: Biodiversity and Management of the Madrean Archipelago III and 7th Conference on Research and Resource Management in the Southwestern Deserts, Tucson, AZ, USA, 1-5 May 2012.

20. Felger, R.S.; Wilson, M.F. Northern Sierra Madre Occidental and its Apachian outliers: A neglected center of biodiversity. In Biodiversity and Management of the Madrean Archipelago: The Sky Islands of Southwestern United States and Northwestern Mexico; 1995; pp. 36-51.

21. O'Connor, C.D.; Falk, D.A.; Lynch, A.M.; Swetnam, T.W. Fire severity, size, and climate associations diverge from historical precedent along an ecological gradient in the Pinaleño Mountains, Arizfona, USA. For. Ecol. Manag. 2014, 329, 264-278. [CrossRef]

22. Yocom, L.L.; Fulé, P.Z.; Falk, D.A.; García-Domínguez, C.; Cornejo-Oviedo, E.; Brown, P.M.; Villanueva-Díaz, J.; Cerano, J.; Montaño, C.C. Fine-scale factors influence fire regimes in mixed-conifer forests on three high mountains in Mexico. Int. J. Wildland Fire 2014, 23, 959-968. [CrossRef]

23. Margolis, E.Q.; Swetnam, T.W.; Allen, C.D. Historical stand-replacing fire in upper montane forests of the Madrean Sky Islands and Mogollon Plateau, southwestern USA. Fire Ecol. 2011, 7, 88-107. [CrossRef]

24. Margolis, E.Q. Fire regime shift linked to increased forest density in a piñon-juniper savanna landscape. Int. J. Wildland Fire 2014, 23, 234-245. [CrossRef]

25. Morino, K.A.; Baisan, C.H.; Swetnam, T.W. Historical Fire Regimes in the Chiricahua Mountains, Arizona: An Examination of Fire along an Elevation Gradient and in Mixed-Confier Forest; Laboratory of Tree-Ring Research, The University of Arizona: Tucson, AZ, USA, 2000.

26. Taylor, A.H.; Poulos, H.M.; Kluber, J.; Issacs, R.; Pawlikowski, N.; Barton, A.M. Controls on spatial patterns of wildfire severity and early post-fire vegetation development in an Arizona Sky Island, USA. Landsc. Ecol. 2021, 36, 2637-2656. [CrossRef]

27. Schoennagel, T.; Balch, J.K.; Brenkert-Smith, H.; Dennison, P.E.; Harvey, B.J.; Krawchuk, M.A.; Mietkiewicz, N.; Morgan, P.; Moritz, M.A.; Rasker, R.; et al. Adapt to more wildfire in western North American forests as climate changes. Proc. Natl. Acad. Sci. USA 2017, 114, 4582-4590. [CrossRef] [PubMed] 
28. Villarreal, M.L.; Iniguez, J.M.; Flesch, A.D.; Sanderlin, J.S.; Cortés Montaño, C.; Conrad, C.R.; Haire, S.L. Contemporary Fire Regimes Provide a Critical Perspective on Restoration Needs in the Mexico-United States Borderlands. Air Soil Water Res. 2020, 13, 1178622120969191. [CrossRef]

29. Villarreal, M.L.; Haire, S.L.; Iniguez, J.M.; Montaño, C.C.; Poitras, T.B. Distant neighbors: Recent wildfire patterns of the Madrean Sky Islands of southwestern United States and northwestern Mexico. Fire Ecol. 2019, 15, 2. [CrossRef]

30. Haire, S.L.; McGarigal, K. Effects of landscape patterns of fire severity on regenerating ponderosa pine forests (Pinus ponderosa) in New Mexico and Arizona, USA. Landsc. Ecol. 2010, 25, 1055-1069. [CrossRef]

31. Haire, S.L.; McGarigal, K. Changes in fire severity across gradients of climate, fire size, and topography: A landscape ecological perspective. Fire Ecol. 2009, 5, 86-103. [CrossRef]

32. Haffey, C.M. Patterns and Predictors of Crown Fire Induced Type Conversion in Dry Conifer Forests; Northern Arizona University: Flagstaff, AZ, USA, 2014.

33. Coop, J.D.; Parks, S.A.; McClernan, S.R.; Holsinger, L.M. Influences of prior wildfires on vegetation response to subsequent fire in a reburned southwestern landscape. Ecol. Appl. 2016, 26, 346-354. [CrossRef]

34. Barton, A.M.; Poulos, H.M. Pine vs. oaks revisited: Conversion of Madrean pine-oak forest to oak shrubland after high-severity wildfire in the Sky Islands of Arizona. For. Ecol. Manag. 2018, 414, 28-40. [CrossRef]

35. Barton, A.M. Pines versus oaks: Effects of fire on the composition of Madrean forests in Arizona. For. Ecol. Manag. 1999, 120, 143-156. [CrossRef]

36. Coop, J.D.; Parks, S.A.; Stevens-Rumann, C.S.; Crausbay, S.D.; Higuera, P.E.; Hurteau, M.D.; Tepley, A.; Whitman, E.; Assal, T.; Collins, B.M. Wildfire-driven forest conversion in western North American landscapes. BioScience 2020, 70, 659-673. [CrossRef]

37. Guiterman, C.H.; Margolis, E.Q.; Allen, C.D.; Falk, D.A.; Swetnam, T.W. Long-term persistence and fire resilience of oak shrubfields in dry conifer forests of northern New Mexico. Ecosystems 2018, 21, 943-959. [CrossRef]

38. Stevens-Rumann, C.S.; Morgan, P. Tree regeneration following wildfires in the western US: A review. Fire Ecol. 2019, 15, 15. [CrossRef]

39. Johnston, B.C. Woodland classification: The pinyon-juniper formation. Gen. Tech. Rep. INT 1989, 160.

40. Wood, M.K.; Scanlon, R.; Cram, D.S. Occurrence of sprouts and seedlings of Pinyon Pines, Alligator Junipers, and Gray Oaks following harvest of fuelwood and prescribed burning. Southwest. Nat. 2012, 57, 51-57. [CrossRef]

41. Márquez Linares, M.A. Distribución, Germinación y Estructura de Poblaciones de Arctostaphylos pungens HBK, y su Relación con el Fuego en Durango, México; Universidad Autónoma de Nuevo León: San Nicolás de los Garza, Mexico, 2004.

42. Arechederra-Romero, L. Southwest Fire Science Consortium Field Trip to the Chiricahua National Monument: Discussion of the Impacts of the 2011 Horseshoe 2 Fire. Environ. Geol. 2012.

43. Drewes, H.; Williams, F. Mineral Resources of the Chiricahua Wilderness Area; US Geological Survey Bulletin: Cochise County, AZ, USA, 1973.

44. Adams, D.K.; Comrie, A.C. The North American Monsoon. Bull. Am. Meteorol. Soc. 1997, 78, 2197-2213. [CrossRef]

45. Minor, J.; Falk, D.A.; Barron-Gafford, G.A. Fire Severity and Regeneration Strategy Influence Shrub Patch Size and Structure Following Disturbance. Forests 2017, 8, 221. [CrossRef]

46. Barton, A.M. Factors controlling plant distributions: Drought, competition, and fire in montane pines in Arizona. Ecol. Monogr. 1993, 63, 367-397. [CrossRef]

47. Barton, A.M.; Teeri, J.A. The ecology of elevational positions in plants: Drought resistance in five montane pine species in southeastern Arizona. Am. J. Bot. 1993, 80, 15-25. [CrossRef]

48. USDA. USDA Plants Database; USDA, 2021. Available online: https://plants.usda.gov/ (accessed on 20 July 2020).

49. Swetnam, T.W.; Baisan, C.H. Fire Histories of Montane Forests in the Madrean Borderlands; United States Department of Agriculture Forest Service: Washington, DC, USA, 1996.

50. Barton, A.M.; Swetnam, T.W.; Baisan, C.H. Arizona pine (Pinus arizonica) stand dynamics: Local and regional factors in a fire-prone madrean gallery forest of Southeast Arizona, USA. Landsc. Ecol. 2001, 16, 351-369. [CrossRef]

51. Swetnam, T.W.; Baisan, C.H.; Brown, P.M.; Caprio, A.C. Fire History of Rhyolite Canyon, Chiricahua National Monument; Cooperative National Park Resources Studies Unit, School of Renewable Natural Resources, University of Arizona: Tucson, AZ, USA, 1989.

52. Eidenshink, J.; Schwind, B.; Brewer, K.; Zhu, Z.-L.; Quayle, B.; Howard, S. A project for monitoring trends in burn severity. Fire Ecol. 2007, 3, 3-21. [CrossRef]

53. Miller, J.D.; Thode, A.E. Quantifying burn severity in a heterogeneous landscape with a relative version of the delta Normalized Burn Ratio (dNBR). Remote Sens. Environ. 2007, 109, 66-80. [CrossRef]

54. QGIS. QGIS Geographic Information System; QGIS, 2020. Available online: qgis.osgeo.org (accessed on 20 July 2020).

55. Parker, A.J. The topographic relative moisture index: An approach to soil-moisture assessment in mountain terrain. Phys. Geogr. 1982, 3, 160-168. [CrossRef]

56. Oksanen, J.; Blanchet, F.G.; Kindt, R.; Legendre, P.; Minchin, P.R.; O’hara, R.; Simpson, G.L.; Solymos, P.; Stevens, M.H.H.; Wagner, H. Package 'vegan'. Community Ecol. Package Version 2013, 2, 1-295.

57. Husson, F.; Josse, J.; Le, S.; Mazet, J.; Husson, M.F. Package 'FactoMineR'. R Package 2016, 96, 698.

58. De Caceres, M.; Jansen, F.; De Caceres, M.M. Package 'indicspecies'. Indicators 2016, 8, 1.

59. Jackman, S.; Tahk, A.; Zeileis, A.; Maimone, C.; Fearon, J.; Meers, Z.; Jackman, M.S.; Imports, M. Package 'pscl'; Political Science Computational Laboratory: Stanford, CA, USA, 2015; Volume 18. 
60. Huffman, D.W.; Floyd, M.L.; Hanna, D.P.; Crouse, J.E.; Fulé, P.Z.; Meador, A.J.S.; Springer, J.D. Fire regimes and structural changes in oak-pine forests of the Mogollon Highlands ecoregion: Implications for ecological restoration. For. Ecol. Manag. 2020, 465, 118087. [CrossRef]

61. Savage, M.; Mast, J.N. How resilient are southwestern ponderosa pine forests after crown fires? Can. J. For. Res. 2005, 35, 967-977. [CrossRef]

62. Strom, B.A.; Fulé, P.Z. Pre-wildfire fuel treatments affect long-term ponderosa pine forest dynamics. Int. J. Wildland Fire 2007, 16, 128-138. [CrossRef]

63. Savage, M.; Mast, J.N.; Feddema, J.J. Double whammy: High-severity fire and drought in ponderosa pine forests of the Southwest. Can. J. For. Res. 2013, 43, 570-583. [CrossRef]

64. Shive, K.L.; Sieg, C.H.; Fulé, P.Z. Pre-wildfire management treatments interact with fire severity to have lasting effects on post-wildfire vegetation response. For. Ecol. Manag. 2013, 297, 75-83. [CrossRef]

65. Roccaforte, J.P.; Fuleé, P.Z.; Chancellor, W.W.; Laughlin, D.C. Woody debris and tree regeneration dynamics following severe wildfires in Arizona ponderosa pine forests. Can. J. For. Res. 2012, 42, 593-604. [CrossRef]

66. Stevens-Rumann, C.S.; Kemp, K.B.; Higuera, P.E.; Harvey, B.J.; Rother, M.T.; Donato, D.C.; Morgan, P.; Veblen, T.T. Evidence for declining forest resilience to wildfires under climate change. Ecol. Lett. 2018, 21, 243-252. [CrossRef] [PubMed]

67. Collins, B.M.; Roller, G.B. Early forest dynamics in stand-replacing fire patches in the northern Sierra Nevada, California, USA. Landsc. Ecol. 2013, 28, 1801-1813. [CrossRef]

68. Young, D.; Latimer, A. Post-fire forest regeneration in a changing climate. Joint Fire Sci. Program Rep. 2017.

69. Barton, A.M. Intense wildfire in southeastern Arizona: Transformation of a Madrean oak-pine forest to oak woodland. For. Ecol. Manag. 2002, 165, 205-212. [CrossRef]

70. Iniguez, J.M.; Swetnam, T.W.; Baisan, C.H. Spatially and temporally variable fire regime on RIncon Peak, Arizona, USA. Fire Ecol. Spec. Issue 2009, 5, 3-21. [CrossRef]

71. Fulé, P.Z.; Covington, W. Spatial patterns of Mexican pine-oak forests under different recent fire regimes. Plant Ecol. 1998, 134, 197-209. [CrossRef]

72. Fulé, P. Effects of an intense wildfire in a Mexican oak-pine forest. For. Sci. 2000, 46, 52-61.

73. Romme, W.H.; Allen, C.D.; Bailey, J.D.; Baker, W.L.; Bestelmeyer, B.T.; Brown, P.M.; Eisenhart, K.S.; Floyd, M.L.; Huffman, D.W.; Jacobs, B.F. Historical and modern disturbance regimes, stand structures, and landscape dynamics in piñon-juniper vegetation of the western United States. Rangel. Ecol. Manag. 2009, 62, 203-222. [CrossRef]

74. Floyd, M.L.; Romme, W.H.; Hanna, D.P.; Hanna, D.D. Historical and Modern Fire Regimes in Piñon-Juniper Woodlands, Dinosaur National Monument, United States. Rangel. Ecol. Manag. 2017, 70, 348-355. [CrossRef]

75. Floyd, M.L.; Clifford, M.; Cobb, N.S.; Hanna, D.; Delph, R.; Ford, P.; Turner, D. Relationship of stand characteristics to droughtinduced mortality in three Southwestern piñon-juniper woodlands. Ecol. Appl. 2009, 19, 1223-1230. [CrossRef] [PubMed]

76. Floyd, M.L.; Hanna, D.D.; Romme, W.H. Historical and recent fire regimes in piñon-juniper woodlands on Mesa Verde, Colorado, USA. For. Ecol. Manag. 2004, 198, 269-289. [CrossRef]

77. Poulos, H.; Gatewood, R.; Camp, A. Fire regimes of the piñon-juniper woodlands of Big Bend National Park and the Davis Mountains, west Texas, USA. Can. J. For. Res. 2009, 39, 1236-1246. [CrossRef]

78. Poulos, H.M.; Reemts, C.M.; Wogan, K.A.; Karges, J.P.; Gatewood, R.G. Multiple wildfires with minimal consequences: Lowseverity wildfire effects on West Texas piñon-juniper woodlands. For. Ecol. Manag. 2020, 473, 118293. [CrossRef]

79. Baisan, C.H.; Morino, K.A. Fire History in Chiricahua National Monument; National Park Service: Washington, DC, USA, 2000.

80. Falk, D.A.; Watts, A.C.; Thode, A.E. Scaling ecological resilience. Front. Ecol. Evol. 2019, 7, 275. [CrossRef]

81. Lanner, R.M. Made for Each Other: A symbiosis of Birds and Pines; Oxford University Press on Demand: Oxford, UK, 1996.

82. Vander Wall, S.B. Dispersal of singleleaf pinon pine (Pinus monophylla) by seed-caching rodents. J. Mammal. 1997, 78, 181-191. [CrossRef]

83. Kane, V.R.; Cansler, C.A.; Povak, N.A.; Kane, J.T.; McGaughey, R.J.; Lutz, J.A.; Churchill, D.J.; North, M.P. Mixed severity fire effects within the Rim fire: Relative importance of local climate, fire weather, topography, and forest structure. For. Ecol. Manag. 2015, 358, 62-79. [CrossRef]

84. Kane, J.M.; Dugi, F.L.; Kolb, T.E. Establishment and growth of pinon pine regeneration vary by nurse type along a soil substrate age gradient in northern Arizona. J. Arid Environ. 2015, 115, 113-119. [CrossRef]

85. Keeley, J.E.; Fotheringham, C. Role of fire in regeneration from seed. Seeds Ecol. Regen. Plant Communities 2000, $2,311-330$.

86. Pausas, J.G.; Bradstock, R.A.; Keith, D.A.; Keeley, J.E. Plant functional traits in relation to fire in crown-fire ecosystems. Ecology 2004, 85, 1085-1100. [CrossRef]

87. Pausas, J.G.; Keeley, J.E. Evolutionary ecology of resprouting and seeding in fire-prone ecosystems. New Phytol. 2014, $204,55-65$. [CrossRef] [PubMed]

88. Barton, A.M.; Poulos, H.M. Response of Arizona cypress (Hesperocyparis arizonica) to the Horseshoe Two Megafire in a southeastern Arizona Sky Island mountain range. Int. J. Wildland Fire 2019, 28, 62-69. [CrossRef]

89. Kaib, M.; Baisan, C.H.; Grissino-Mayer, H.D.; Swetnam, T.W. Fire History of the Gallery Pine-Oak Forests and Adjacent Grasslands of the Chiricahua Mountains of Arizona; General Technical Report RM; United States Department of Agriculture Forest Service: Tucson, AZ, USA, 1996; pp. 253-264. 
90. Davis, K.T.; Dobrowski, S.Z.; Higuera, P.E.; Holden, Z.A.; Veblen, T.T.; Rother, M.T.; Parks, S.A.; Sala, A.; Maneta, M.P. Wildfires and climate change push low-elevation forests across a critical climate threshold for tree regeneration. Proc. Natl. Acad. Sci. USA 2019, 116, 6193-6198. [CrossRef] [PubMed]

91. Owen, S.M.; Sieg, C.H.; Sánchez Meador, A.J.; Fulé, P.Z.; Iniguez, J.M.; Baggett, L.S.; Fornwalt, P.J.; Battaglia, M.A. Spatial patterns of ponderosa pine regeneration in high-severity burn patches. For. Ecol. Manag. 2017, 405, 134-149. [CrossRef]

92. Peeler, J.L.; Smithwick, E.A. Seed source pattern and terrain have scale-dependent effects on post-fire tree recovery. Landsc. Ecol. 2020, 35, 1945-1959. [CrossRef]

93. Harris, L.; Taylor, A.H. Topography, fuels, and fire exclusion drive fire severity of the Rim Fire in an old-growth mixed-conifer forest, Yosemite National Park, USA. Ecosystems 2015, 18, 1192-1208. [CrossRef]

94. Harris, L.B.; Taylor, A.H. Rain-shadow forest margins resilient to low-severity fire and climate change but not high-severity fire. Ecosphere 2020, 11, e03258. [CrossRef]

95. Bonnet, V.H.; Schoettle, A.W.; Shepperd, W.D. Postfire environmental conditions influence the spatial pattern of regeneration for Pinus ponderosa. Can. J. For. Res. 2005, 35, 37-47. [CrossRef]

96. Downing, W.M.; Krawchuk, M.A.; Coop, J.D.; Meigs, G.W.; Haire, S.L.; Walker, R.B.; Whitman, E.; Chong, G.; Miller, C.; Tortorelli, C. How do plant communities differ between fire refugia and fire-generated early-seral vegetation? J. Veg. Sci. 2020, 31, 26-39. [CrossRef]

97. Meddens, A.J.; Kolden, C.A.; Lutz, J.A.; Smith, A.M.; Cansler, C.A.; Abatzoglou, J.T.; Meigs, G.W.; Downing, W.M.; Krawchuk, M.A. Fire refugia: What are they, and why do they matter for global change? BioScience 2018, 68, 944-954. [CrossRef]

98. Krawchuk, M.A.; Meigs, G.W.; Cartwright, J.M.; Coop, J.D.; Davis, R.; Holz, A.; Kolden, C.; Meddens, A.J. Disturbance refugia within mosaics of forest fire, drought, and insect outbreaks. Front. Ecol. Environ. 2020, 18, 235-244. [CrossRef]

99. Lauvaux, C.A.; Skinner, C.N.; Taylor, A.H. High severity fire and mixed conifer forest-chaparral dynamics in the southern Cascade Range, USA. For. Ecol. Manag. 2016, 363, 74-85. [CrossRef]

100. Cook, B.I.; Ault, T.R.; Smerdon, J.E. Unprecedented 21st century drought risk in the American Southwest and Central Plains. Sci. Adv. 2015, 1, e1400082. [CrossRef]

101. Ault, T.R.; Mankin, J.S.; Cook, B.I.; Smerdon, J.E. Relative impacts of mitigation, temperature, and precipitation on 21st-century megadrought risk in the American Southwest. Sci. Adv. 2016, 2, e1600873. [CrossRef]

102. Adams, M.A. Mega-fires, tipping points and ecosystem services: Managing forests and woodlands in an uncertain future. For. Ecol. Manag. 2013, 294, 250-261. [CrossRef]

103. Abatzoglou, J.T.; Kolden, C.A. Relationships between climate and macroscale area burned in the western United States. Int. J. Wildland Fire 2013, 22, 1003-1020. [CrossRef]

104. Singleton, M.P.; Thode, A.E.; Meador, A.J.S.; Iniguez, J.M. Increasing trends in high-severity fire in the southwestern USA from 1984 to 2015. For. Ecol. Manag. 2019, 433, 709-719. [CrossRef]

105. Kemp, K.B.; Higuera, P.E.; Morgan, P.; Abatzoglou, J.T. Climate will increasingly determine post-fire tree regeneration success in low-elevation forests, Northern Rockies, USA. Ecosphere 2019, 10, e02568. [CrossRef]

106. Liang, S.; Hurteau, M.D.; Westerling, A.L. Response of Sierra Nevada forests to projected climate-wildfire interactions. Glob. Chang. Biol. 2017, 23, 2016-2030. [CrossRef] [PubMed]

107. O'Connor, C.D.; Falk, D.A.; Garfin, G.M. Projected climate-fire interactions drive forest to shrubland transition on an Arizona sky island front. Environ. Sci. 2020,8.

108. Yanahan, A.D.; Moore, W. Impacts of 21st-century climate change on montane habitat in the Madrean Sky Island Archipelago. Divers. Distrib. 2019, 25, 1625-1638. [CrossRef]

109. Gratani, L. Plant Phenotypic Plasticity in Response to Environmental Factors. Adv. Bot. 2014, 2014, 17. [CrossRef]

110. Hess, V.A.; Fule, P.Z. Is a Mexican pine species better adapted to the warming climate of the southwestern USA? Front. For. Glob. Chang. 2020, 3, 60. [CrossRef] 